IZA DP No. 6859

Media Slant Against Foreign Owners: Downsizing

Guido Friebel

Matthias Heinz

September 2012

Forschungsinstitut zur Zukunft der Arbeit Institute for the Study of Labor 


\title{
Media Slant Against Foreign Owners: Downsizing
}

\author{
Guido Friebel \\ Goethe University Frankfurt, \\ CEPR and IZA \\ Matthias Heinz \\ Goethe University Frankfurt
}

\section{Discussion Paper No. 6859 \\ September 2012}

\author{
IZA \\ P.O. Box 7240 \\ 53072 Bonn \\ Germany \\ Phone: +49-228-3894-0 \\ Fax: +49-228-3894-180 \\ E-mail: iza@iza.org
}

Any opinions expressed here are those of the author(s) and not those of IZA. Research published in this series may include views on policy, but the institute itself takes no institutional policy positions. The IZA research network is committed to the IZA Guiding Principles of Research Integrity.

The Institute for the Study of Labor (IZA) in Bonn is a local and virtual international research center and a place of communication between science, politics and business. IZA is an independent nonprofit organization supported by Deutsche Post Foundation. The center is associated with the University of Bonn and offers a stimulating research environment through its international network, workshops and conferences, data service, project support, research visits and doctoral program. IZA engages in (i) original and internationally competitive research in all fields of labor economics, (ii) development of policy concepts, and (iii) dissemination of research results and concepts to the interested public.

IZA Discussion Papers often represent preliminary work and are circulated to encourage discussion. Citation of such a paper should account for its provisional character. A revised version may be available directly from the author. 
IZA Discussion Paper No. 6859

September 2012

ABSTRACT

\section{Media Slant Against Foreign Owners: Downsizing*}

We establish the existence of strong media slant against foreign owners. Using a unique data set from nation-wide distributed quality newspapers in Germany, we find that a foreign firm that downsizes in Germany receives almost twice as much attention than a domestic firm. This quantitative slant is accompanied by qualitative slant; newspapers report in a more negative way about downsizing foreign than domestic firms. The slant is present in all quality newspapers, but it increases from right to left in the political spectrum. This is consistent with theory papers arguing that slant is an equilibrium phenomenon. The slant we document is a clean measure for economic xenophobia; however, not geared against migrants, but against foreign owners. The slant can be a substantial obstacle to FDI, as illustrated by case studies. Our results are likely to be a lower bound estimate, because Germans are rather globalization-friendly and we are looking at quality papers, not tabloids.

JEL Classification: L82, L33, L10

Keywords: media economics, globalization, economic xenophobia, multi-national enterprises, foreign direct investment

Corresponding author:

Guido Friebel

Goethe University Frankfurt

Chair of Human Resource Management

P.O. Box 52

Grüneburgplatz 1

60629 Frankfurt

Germany

E-mail: gfriebel@wiwi.uni-frankfurt.de

\footnotetext{
* We thank Simon Anderson, Iwan Barankay, Sascha Becker, Stefan Bender, Paolo Cox, Stefano DellaVigna, Klaus Desmet, Ruben Durante, Karolina Ekholm, Ruben Enikolopov, Matthew Gentzkow, Lisa George, Fabrizio Germano, Maria Guadalupe, Sergei Guriev, Peter Haan, Andrea Ichino, Niels Kemper, Joep Konings, Michael Kosfeld, Olga Kuzmina, Christian Leuz, Alexander Lipponer, MarcAndreas Muendler, Volker Nocke, Maria Petrova, Riccardo Puglisi, Isabell Schnabel, Andrei Shleifer, Monika Schnitzer, Eugene Soltes, David Strömberg, Jo Swinnen, Natalya Volchkova, Joel Waldfogel, Jörgen Weibull, Ekaterina Zhuravskaya and seminar participants in Frankfurt, KU Leuven and Stockholm School of Economics for their comments. We also thank conference audiences at the European Economic Association Meeting in Oslo 2011 and the $9^{\text {th }}$ Workshop on Media Economics in Moscow 2011. We are grateful to MediaTenor and YouGov for access to data.
} 


\section{Introduction}

Using a unique data set on nation-wide distributed quality newspapers in Germany, we establish the existence of strong media slant against foreign owners. On average, firms that are controlled by foreign blockholders attract close to double the media attention for each job shed than domestic firms. More articles are written about downsizing when owners are foreign, and in an average article, more of the words written concern downsizing rather than firm performance, products or strategies. Quantitative slant is accompanied by qualitative slant; newspapers report more negatively about downsizing in foreign-owned firms.

Our estimates are likely to be a lower bound of media slant against foreign owners, because Germany is a leading export country (second to China only), Germans are among the peoples most positive about globalization (on a level that is above the one of the U.S. ${ }^{2}$ ), and because we look at quality not regional newspapers or tabloids.

The slant we find is a clean measure of economic xenophobia, here, geared against foreign owners rather than targeting the most likely victims of economic xenophobia, migrants. When moving from right to left on the political spectrum of newspapers, the slant against foreign owners increases. The slant is likely to cause severe obstacles to FDI and, thus, global inefficiencies. Foreign firms that anticipate negative media attention and penalties by domestic consumers will price in the risk, leading to discounts in the case of FDI. Foreigners may even refrain from buying firms that are candidates for downsizing or substantial media interest. These implications are testable, although we are lacking the data. In Section 2, we do, however, provide short case studies that give an idea of the multi-million penalty consumers can inflict on a downsizing foreign firm.

In the remainder of the Introduction, we explain how the data were generated and analyzed, and how our findings relate to empirical and theoretical work in media economics. Most importantly, we argue that our paper may be among the first to empirically support some of the leading theories on the industrial organization of media, in particular, Sendhil Mullainathan and Andrei Shleifer (2005) and Matthew Gentzkow and Jesse Shapiro (2006).

Our first data set is based on 5,394 articles from Germany's center-right newspaper Die Welt on a total of 651 downsizing events in Germany between December 2000 and September 2008. ${ }^{3}$ Following Gentzkow's and Shapiro's (2006) definition of slant, we focus on the varying intensity of reporting a given fact, measured by the number of words the

\footnotetext{
${ }^{2}$ Cf Anna-Maria Mayda and Dani Rodrik (2005).

${ }^{3}$ We end with September 2008, because the collapse of Lehman Brothers triggered a wave of downsizing and state interventions, and we are interested in normal, rather than special times.
} 
newspaper writes per job shed in downsizing events of foreign-owned employers, relative to domestic ones. A second data set from the media consultancy Media Tenor allows to measure the different qualitative evaluations involved. We also collected a third data set that includes all articles on downsizing during five randomly chosen months from all nation-wide distributed quality newspapers in Germany.

To build the first data set we developed an algorithm that excludes both the errors of including "false" and failing to include "real" downsizing cases (explained in detail in Section 3). Our regressions (Section 4) show a strong media slant against foreign-owned firms; it is robust against the inclusion of a battery of control variables, such as 40 sectors, 16 regions, time dummies, or size of the downsizing firm. The absolute magnitude of downsizing and its importance relative to firm size cannot explain the slant either.

Interestingly, the slant against foreign firms is stronger when the region's unemployment rate in which the downsizing occurs is higher. Local unemployment does, however, not matter for the intensity of reports on domestic firms' downsizing activities.

Investigating potential spurious correlations (in Section 5) we find that the results are robust against inclusion of the reason for downsizing (off-shoring, M\&A etc), the type of ownership (publicly listed, private-equity owned etc), and the country of origin of the owners. The newspaper has no tendency to report more about foreign firms in general, or about positive news like job creation, i.e. upsizing of foreign-owned firms.

The slant is unrelated to technological factors, like the size of standard articles in different newspapers sections such as title page, business and economics, politics, or to the timing of the news, as in Eugene Soltes (2009). We also use matching techniques as in Sascha Becker and Andrea Ichino (2002) and Paul Rosenbaum and Donald Rubin (1983) to make sure that the effects are not caused by endogenous sorting of foreign firms in specific regions or sectors that may receive more attention.

If foreign firms downsized more intensively than domestic firms, there could be a rationale for media to report more on "foreign" downsizing, for instance, to make people aware of the higher risk of losing one's job. Most of the FDI literature does, however, not find evidence that foreign multi-national enterprises (MNEs) are more footloose than domestic ones. ${ }^{4}$ Christine Borrmann, Rolf Jungnickel and Dietmar Keller (2003) find that foreign firms are similar to domestic firms in terms of participation in collective bargaining and employing

\footnotetext{
${ }^{4}$ Giorgio Barba Navaretti and Anthony Venables (2004), Claudia Buch and Alexander Lipponer (2010).
} 
works councils. They have similar turnover rates and similar shares of part-time and fixedterm contract workers.

A notable exception is Becker and Marc-Andreas Muendler (2010) who document that German MNEs tend to adjust at the intensive margin in Western Europe, but rather at the extensive margin in Central and Eastern Europe. Because almost all firms in our sample are MNEs, with roughly one third controlled by foreign blockholders, we can investigate whether the slant is driven by a similar firm behavior of foreign firms at the extensive margin. ${ }^{5}$ Looking at the closure of establishments (the extensive margin), we do not find any effects. There is thus little reason to believe that foreign firms behave differently from domestic ones.

Nonetheless, Die Welt seems to cater to the fear of the population that jobs in foreignowned firms may be less safe. Kenneth Scheve and Matthew Slaughter (2006) phrased these beliefs as follows: "people perceive an asymmetric distribution of the benefits of globalization: more for consumers and corporations, but less for workers". Surprisingly, this is even true for Germany, one of the most globalization-friendly countries, and for Die Welt that is owned by the Axel Springer Publishing House ${ }^{6}$, a close ally of the business-friendly CDU party that has been in government since 2005. But the readership of Die Welt is conservative, and conservatism may trigger some bias against foreign owners. This raises the question how slant correlates with the political orientation of newspapers.

We hence set up a third data set including five randomly drawn months of reports from the six other leading national newspapers: Handelsblatt and Financial Times Deutschland (FTD), finance and business newspapers; the Frankfurter Allgemeine Zeitung (FAZ), right-of-center, and close to business; the Süddeutsche Zeitung (SZ) and Frankfurter Rundschau (FR), left-of-center; and Die Tageszeitung (TAZ) a left-wing newspaper. Together with Die Welt these newspapers have a total of 1.55 million sold copies in 2000 (1.56 million in 2008) and represent around $90 \%$ of the national quality newspaper market in Germany.

We find that all newspapers slant their reports in the same direction, but the FTD does so with the weakest intensity, followed by Handelsblatt, Die Welt, FAZ, SZ, FR and TAZ. The slant against foreign owners hence increases when moving from right to left along the

\footnotetext{
${ }^{5}$ It should be noted that we look at operations of MNEs in Germany, which is not a low labor-cost country. Hence, the public perception that globalization poses a threat to employment by outsourcing to countries with cheaper labor than in the countries of origin of the respective MNEs is not relevant. It is also noteworthy that the existing evidence is not in line with the public perception, see, for instance, Henrik Braconier and Karolina Ekholm (2000), Jozef Konings and Alan-Patrick Murphy (2006) and Dalia Marin (2004).

${ }^{6}$ The family Springer owned the majority of the publicly listed Axel Springer Publishing House throughout the entire period. In the meanwhile the media entrepreneur Leo Kirch, the Deutsche Bank, the private equity firm Hellman \& Friedman hold larger minority stakes in the company.
} 
political spectrum, with the left-wing TAZ having a slant that is more than twice as strong as Die Welt. These results are consistent with the presence of a general bias among the readership of all newspapers, which is strongest for the left-wing, anti-globalization and anticapitalist readership of TAZ. As the newspapers we look at are aiming at a rather educated readership compared to the main tabloids or the regional newspapers, we would expect the slant in other media to be even stronger.

Inasmuch as our paper documents a robust slant against foreign owners, which increases from right to left on the political spectrum, and which has potentially serious implications on household and firm decisions, we contribute to a growing empirical literature on media economics. There are studies about the ideological position of media (e.g. Gentzkow and Shapiro, 2010; Timothy Groseclose and Jeffrey Milyo, 2005), the impact of media on voting turnout (e.g. Gentzkow, Shapiro and Michael Sinkinson, 2011; Felix Oberholzer-Gee and Joel Waldfogel, 2009) and on electoral outcomes (e.g. Stefano DellaVigna and Ethan Kaplan, 2007; Ruben Durante and Brian Knight, 2012; Ruben Enikolopov, Maria Petrova and Ekaterina Zhuravskaya, 2011). Other studies analyze the impact of media on political outcomes (e.g. Timothy Besley and Robin Burgess, 2002; Thomas Eisensee and David Strömberg, 2007; Strömberg, 2004; James Snyder and Strömberg, 2010) and household decisions (e.g. Benjamin Olken, 2009).

However, there is little empirical work allowing inferences on the functioning of media markets. ${ }^{7}$ The empirical paper we are closest to is Gentzkow and Shapiro (2010) who find that newspapers tailor their slant to the beliefs of their potential readers. They do not find evidence of owner bias. We come to a similar conclusion. The newspapers are owned by quite different owners, like foundations, cooperatives, families, international media companies and political parties; it is hard to believe that all of them are biased against foreign owners. Moreover, three of the newspapers changed the owner in our period of observation, without noticeable impact on the slant.

What theories are then consistent with our results? We carry out a number of additional analyses in Section 6 to investigate this question. David Baron (2006) considers a supply side explanation for media bias. ${ }^{8}$ Certain journalists may have preferences for certain

\footnotetext{
${ }^{7}$ Contributions include Andrew Sweeting $(2007,2010)$ on product positioning in radio stations, Lisa George (2007) on the effect of concentration on news variety, and Caitlin Knowles Myers (2005) on racial diversity and discrimination in competitive media markets. None of these, however, try to explain news slant as an equilibrium phenomenon.

${ }^{8}$ We have so far used the term "slant" rather than " bias", as the literature tends to associate bias with behavior that is not in line with profit maximization (Gentzkow and Shapiro, 2010). Here (and in the
} 
news, for instance to show that foreign firms are "bad" for domestic workers. The newspaper may allow them to report in a biased way to retain the journalists or cut wage costs. Identifying 15 journalists who frequently write on downsizing and comparing their slant with the one of the total population, we can exclude that the slant of some journalists is driving the slant, though we cannot exclude that all journalists are biased against foreign owners.

Similarly, in a subsample of downsizing events in which we identify advertising clients, we find no evidence of advertisers' influence (as in Jonathan Reuter and Eric Zitzewitz, 2006; and in Marco Gambaro and Riccardo Puglisi, 2010). Political economy explanations like Besley and Andrea Prat's (2006) do not apply very well either, as governments had no interest to influence the media against foreign owners given that throughout the entire period we look at, as Germany was run by the globalization-friendly Schröder and Merkel governments. Puglisi (2011) finds differences in the agenda-setting behavior of the New York Times during presidential-campaign and no-campaign periods in the U.S. Thus, we also compared the coverage about downsizing before important German elections with no-campaign periods. Indeed, politicians may be tempted in such periods to use foreign owners as scapegoats in debates about downsizing. However, as shown in Table A in the web appendix, ${ }^{9}$ we do not find any systematic differences. ${ }^{10}$

Psychological factors could play a role. A "fear of the unknown" would predict the bias to be strongest for the countries with larger cultural, geographical or genetic distance. Similarly, aversions could be based on rather general perceptions of "free" market-based economic systems like the one of the U.K. or the U.S. compared to the continental European "social" market economy. Controlling for groups of countries of origin does, however, not change the picture. Indeed, we find a bias against all groups of countries.

We here thus seem to look at an interesting equilibrium phenomenon in which newspapers report with a higher intensity on downsizing cases of foreign owners because there is a general belief that foreign owners are worse for jobs in Germany. This strong evidence of an "agenda-setting effect" (Maxwell McCombs and Donald Shaw, 1972), i.e. the influence media exert on the importance people attach to a given object, is in line with a theoretical literature that analyzes the market for news.

respective parts of the paper), we prefer using the word "bias", as it describes individual behavior that is not necessarily in line with profit maximization.

${ }^{9} \mathrm{http}: / /$ www.mm.uni-frankfurt.de/index.php?id=1528

${ }^{10}$ There is a noteworthy exception. The leader of the SPD, the German social democrats, conducted a short campaign against what he called "locusts", foreign private equity investors. We do find a slight increase in the slant during that period, but the slant is present across the entire period. 
The paper most related is by Mullainathan and Shleifer (2005) who assume that newspapers receive an identical signal about the truth, but can slant their stories by omitting some of the information. When readers have a preference for news that is consistent with their initial beliefs, oligopolistic newspapers can charge higher prices by differentiating themselves through slanted reports. The fact that we find slant against foreign owners across the political spectrum of newspapers is an indication that the underlying beliefs of the population are biased in a relatively homogeneous way. Otherwise, we should also see slant in favor of foreign owners. The example given for homogenous beliefs in Mullainathan and Shleifer (2005) is foreign policy; it seems that the beliefs about foreign-owned firms as being bad for jobs are similarly homogeneous in the population. Gentzkow and Shapiro (2006) generate slant in a theory in which consumers think that newspapers that share their perspectives are more reliable and therefore provide more valuable information. Thus slant arises as a natural consequence of newspapers' desire to build a reputation for accuracy. Simon Anderson and John McLaren (2012) show that similar mechanisms prevail when consumers are fully rational.

These theories are quite in line with what we find. In the case of downsizing by foreign firms, all newspapers slant the news into the same direction, albeit with different intensity. This indicates that on some dimensions, initial beliefs may be highly skewed. Arguably, employment in and downsizing by foreign firms may be one of them. Media slant then may not only account for persistence of this view, but may enforce it.

\section{Case studies on media slant and FDI}

The case of Nokia, the global Finish mobile-phone maker, provides an idea of the consequences of negative perceptions of a firm, which are likely to be triggered or exacerbated by media reports. Nokia's decision to shut down its plant in Bochum, Germany (a loss of 2,300 jobs) in January 2008, was accompanied by massive negative attention by the media. Nokia lost 8 percentage points in the German mobile phone market during the following six months; in the rest of Europe, its market share staid constant. ${ }^{11}$

We estimate that Nokia lost 220 million Euro of sales after the downsizing, based on the following back-of-the-envelope computation. In 2007, Nokia sold 12 million mobile phones in Germany, representing a 44\% market share. At an average price of $110 €$ per mobile

\footnotetext{
11 These figures come from GfK, a market research institute, and are documented in several newspapers and magazines, e.g. Capital.de (http://www.capital.de/unternehmen/100016963.html).
} 
phone, a loss of 8 percentage points of market share (i.e. 2 million sales) implies a fall in turnover of 220 million Euro in 2008.

There was also massive reputational damage as documented by the market research institute YouGov. ${ }^{12}$ Average quality ratings of Nokia mobile phones fell from +50 two weeks before the announcement to +1 two weeks afterwards (on a scale from +100 to -100 ); the willingness to recommend Nokia products fell from +42 to -15 , and the perceived priceperformance ratio from +31 to -6 . Even nine months after the announcement, the ratings for Nokia products had not reached half the pre-announcement level. ${ }^{13}$ As nothing happened to the mobile phones as such, this is a mystery, unless the media reports are taken into account.

At the same time, BMW shed 7,500 jobs, mainly in Leipzig, Eastern Germany, a much larger job loss of an equally well-known brand, in a region plagued by a higher unemployment rate. $B M W$, controlled by a German block-holder, received little media attention, the YouGov ratings stayed roughly constant ${ }^{14}$ and in 2008, BMW gained the largest market share in their history.

A second example are white-goods manufacturers Miele, Bosch Siemens HHG (both German) and Swedish Electrolux. All announced to shed jobs in 2005 (Miele 1,078, BSH 420, Electrolux 1,750) in Germany. Electrolux's downsizing led to four times more articles in Die Welt as Miele and BSH. In 2006, Miele and BSH increased their joint market share in Germany by 5.2 percentage points. Electrolux lost 4 percentage points, while in the rest of Europe, its market share staid constant. ${ }^{15}$

We cannot claim that these effects were entirely caused by media reports. Rather, they are good illustrations of the potentially substantial real effects of media. There are numerous cases were downsizing of foreign firms in Germany was accompanied by massive negative media attention, but we are lacking the data to estimate the negative effects of media attention. Examples include Grohe (a sanitary facilities manufacturer, owned by Swiss, U.S. and U.K. private equity investors) in 2005, BenQ, the Taiwan electronics firm, in 2006 or, in the past and at present again, Opel (owned by GM).

\footnotetext{
${ }^{12}$ These data are not publicly available, but can be provided by the authors upon request.

${ }^{13}$ In June 2008 (September 2008), the average quality rating of Nokia phones was $+14.4(+19)$, the willingness to recommend Nokia products $+4.2(+11)$, and the perceived price-performance ratio +1.8 $(+9)$.

${ }^{14}$ The quality rating increased slightly $(+48$ to +52$)$, the willingness to recommend $B M W$ products stayed constant $(+31$ to +31$)$ and the price-performance rating decreased slightly +12 to +4 .

${ }^{15}$ These figures also come from GfK and are documented in several newspapers and magazines, e.g. Nürnberger Nachrichten (http://www.nordbayern.de/nuernberger-nachrichten/wirtschaft/electroluxmachte-mehr-gewinn-1.761846).
} 


\section{Data}

\subsection{Identifying articles about downsizing}

Surprisingly, there is no data set on downsizing in Germany. The German Labor Agency records data without distinguishing announcements from final downsizing decisions. We hence identify downsizing cases through the media data base LexisNexis including only those articles for which both firm identity and the actual number of jobs shed are known. ${ }^{16}$

The following algorithm assures to include "true" downsizing cases, and to exclude "false" cases. We first identified a list of direct German synonyms for the word downsizing (these can be found in Appendix II). Some terms are readily identifiable but the precise sense of other terms depends on the context. As many of these terms are composed by several words ("Standortschließung" = shut-down of a plant), setting up the list of synonyms required reading thousands of articles.

The goal of the second step of the analysis was to verify our understanding of terms related to downsizing. It involved the paid assistance of twenty students from different fields of study. ${ }^{17}$ All students received a translated version of William Baumol, Alan Blinder, and Edward Wolff's (2003) definition of downsizing. ${ }^{18}$ One group of students was then asked to write down their own list of synonyms for downsizing so to make sure that we did not miss words that others would perceive as synonyms. Another group received a list of forty words out of which eight were from our list of direct synonyms for downsizing, seventeen were context-dependent, ${ }^{19}$ and fifteen had nothing to do with downsizing (e.g., "Fehlbetrag", deficit). This group of students was asked to indicate to what extent these words describe downsizing on a scale from "by no means" (1) to "by all means" (5). The eight downsizing synonyms had an average of 4.43 with a standard deviation of 0.24 ; the seventeen contextdepending terms had an average of 3.61 (s.d. 0.45), and the terms not related to downsizing had an average score of 2.19 (s.d. 0.56).

\footnotetext{
${ }^{16}$ In Appendix II, we provide examples of articles that did and did not qualify to be included in our data base, for one of the reasons above.

${ }^{17}$ The experiment took place at the FLEX laboratory in Frankfurt. Participants were recruited using the online recruiting system ORSEE $®$ (Ben Greiner, 2004) and had no further information about the research. Each participant received a fixed wage of 5 Euros, the job took them around half an hour.

${ }^{18}$ They define downsizing on page 63 as follows: "Downsizing, a term coined by journalists, seems to have no agreed-upon definition. It is clear, however, that the most salient feature of the phenomenon (...) is shrinkage in employment. So it seems natural to say that a firm downsizes when it trims its workforce - even if the reduced workforce, perhaps supplemented by more capital, produces just as much (or even more) output as it did before."

${ }^{19}$ The German word for restructuring ("Restrukturierung"), for instance, may be used for downsizing as well as for financial matters. Appendix II lists the many words that without the right context would not be immediately identifiable as a synonym for downsizing.
} 
The third step is similar to the one of Eisensee and Strömberg (2007) who searched articles with keywords like "Tsunami" and "Earthquake" and the name of the affected country. We identified all articles in the data base in which one or several of the synonyms for downsizing appeared, and then searched all articles on the 498 firms mentioned in these articles. In total, we looked at almost 40,000 articles in which downsizing companies are somehow mentioned. We thus avoid missing cases in which none of the downsizing synonyms appeared but in which the focus was nonetheless downsizing. We ended up with 5,394 articles about a total of $424^{20}$ companies and 651 downsizing cases.

The fourth step involved the help of another 24 students: ${ }^{21}$ twelve students received a package of 40 articles of which ten articles each related to downsizing at the DZ Bank and Altana (these firms were chosen randomly). There were another ten articles each on the same two companies we considered as being unrelated to downsizing. Students were asked for each article whether or not they were related to downsizing. Excluding the "do not know" and "no statement possible" categories, there was a 96.2\% congruence between their and our classification, while including these answers, the congruence was $90 \%$. The other twelve students received twenty randomly chosen articles on the downsizing of various firms, and twenty randomly chosen articles registered as unrelated to downsizing, in a randomly chosen, small span of time (Aug. $20^{\text {th }}, 2004$ to Sept. $6^{\text {th }}, 2004$ ). The congruence was $93.6 \%$ excluding the "do not know" and "no statement possible" answers; including them the congruence was $82 \%$. These checks confirm our data strategy. It is also interesting that a sequence of articles rather than a single article on a given firm increased the students' and our congruence. We interpret this as support for our strategy to look at all articles on any given downsizing case.

In each article, we counted the words in the paragraphs in which at least one synonym for downsizing appeared. In some cases, all paragraphs in an article were on downsizing, in others downsizing only played a role in some of the paragraphs. Counting words in paragraphs with downsizing synonyms rather than in the entire article is very important. There are articles in which the bulk of paragraphs may be on a new strategy or a new CEO, and downsizing only appears as a minor issue, while others may be entirely devoted to downsizing. The descriptive statistics show that the proportion of an article which is devoted to downsizing constitutes an important distinction between the reports on domestic versus foreign firms.

\footnotetext{
${ }^{20}$ For additional 74 firms, we found reports about rumors, or announcements of downsizing, but no information about the number of jobs shed. These cases were not entered into the data set.

${ }^{21}$ The students received the same definition of downsizing as the others, and each received a fixed payment of 10 Euros for a job that took them on average less than an hour.
} 
We also made sure that to only record articles on foreign firms' downsizing when we could verify that German locations were indeed affected by downsizing of this company. In most downsizing events, the total number of jobs shed are mentioned in Die Welt's articles. We checked for consistency in other quality media, in agency reports like Reuters and DPA and with information from the company like annual reports, and press communiqués. If there remained doubts about the total numbers of job sheds, we omitted the entire downsizing case.

\subsection{Descriptive statistics}

In our dataset, one observation is one downsizing event (or "case") by one firm. We use two left-hand-side variables: (i) the number of articles; (ii) the number of words summed over all articles on the downsizing event. The variables are normalized by the total number of jobs shed in the event. In total, we have 5,394 articles about 424 companies and 651 downsizing cases.

\subsubsection{Downsizing events and firms in the data set}

Table 1 provides an overview about downsizing events broken down by two-digit industry classification and by the type of firm; domestic versus foreign. Except for seven out of 39 industries, there is at least one domestic and one foreign firm in each industry.

\section{TABLES 1, 2 ABOUT HERE}

Our classification in domestic versus foreign firms (see Table 2) is based on the prescriptions of German law. Only shareholders who own an equity share of $25 \%$ or more have special control rights (e.g. they can convene extraordinary general meetings). In 426 of our cases, foreign blockholders hold less than $25 \%$ of the equity of the firm. These are treated as domestic firms. ${ }^{22}$ In 209 cases foreign blockholders have more than $25 \%$. There are no cases with foreign blockholders owning between $26 \%$ and $44 \%$ of the shares. Two downsizing cases are from $E n B W(45 \%$ owned by German public authorities, and $45 \%$ by Électricité de France). In four downsizing cases, the owners were a 50/50 joint venture between foreign and domestic firms (involving Siemens and Carl Zeiss). Because of their

\footnotetext{
${ }^{22}$ Two comments apply. First, there are just nine downsizing cases with smaller, but substantial foreign blockholders: Bertelsmann (with $25 \%$ ownership by the Belgian Group Bruxelles Lambert and $75 \%$ owned by the Mohn family and their Bertelsmann Foundation); Daimler-Chrysler (with Kuwait as an $18 \%$ blockholder) and Deutsche Börse (with two hedge funds holding a total of $20 \%$ ). In the other 417 cases, there were no substantial (i.e, more than 10\%) foreign blockholders in the relevant downsizing periods. 151 of these cases have no substantial German blockholders. In order to exclude any possible influence of some cases in which firms could be perceived as foreign firms because a small foreign investor may be very active and no German blockholder is present, we carried out a robustness check excluding all these firms. As shown in Chapter 5.1 this has no effect on our results.
} 
substantial foreign blockholders, we will count the above six cases as foreign firms. In total, we hence have 426 downsizing cases with domestic and 209 with foreign owners. ${ }^{23}$

In Panel B of Table 2, there are 16 downsizing events of 12 companies for which we could not clearly classify the firms. In eight events, ownership changed between foreign and domestic or vice versa during the period of downsizing, e.g. Deutsche $B A$, which was sold by British Airways to a German entrepreneur during downsizing. Moreover, two firms had shared or unclear control rights ${ }^{24}$ and two firms (i.e. six downsizing-cases) had two headquarters, one in Germany and one in a foreign country. ${ }^{25}$ In the dataset used for the regressions we exclude those cases. However, throughout the paper we carry out a number of robustness checks to make sure that the classification between domestic and foreign firms and inclusion or exclusion of unclear cases is not crucial for any of the results. Without these hybrid firms, the final dataset used in the regressions contains 5,172 articles from 412 companies and 635 downsizing cases.

\section{TABLE 3 ABOUT HERE}

Panel A of Table 3 provides an overview of the size of firms in our sample in terms of workers in Germany. We distinguish between firms employing 750 or less, 751-2,500, 2,5017,500 and more than 7,500 workers in Germany. As expected, foreign firms are underrepresented in the class of very large firms. Panel B summarizes the magnitudes of downsizing events, the respective number of jobs lost. We distinguish between companies who shed 150 or less, 151-750 and more than 750 jobs. There are slightly fewer large downsizing events by foreign firms. Except for these minor differences, the shares of different companies in the respective size classes are more or less the same in all categories. It appears that in terms of distribution across industries, firm size and size of the downsizing event, there are no great differences between foreign and domestic firms. In order to be sure that none of these minor differences between domestic and foreign drives our main results, we will apply propensity score techniques (see section 5.2 and 5.4).

\footnotetext{
${ }^{23}$ Indirect ownership could pose a problem for our classification. In our data set, this would only be a problem for private equity investors, none of which are headquartered in Germany. Hence those firms are classified as foreign. We also control for private equity and ownership in some of the regressions, and find that this has little impact on the significance of the "foreign" dummy.

${ }^{24} R W E$ and Veolia hold together $49.9 \%$ of the equity of Berlinwasser. The shares where pooled in a holding; the company was managed by two CEOs, one appointed by RWE and the other by Veolia. The second case is Deutsche Wohnen. Oaktree Capital held 22.6\% of the equity. In 2007, Oaktree put pressure on the CEO to restructure the firm, who refused. Oaktree initiated an extraordinary general meeting, where the CEO was dismissed. The new CEO directly started to downsize.

${ }^{25}$ Those firms are Intershop, a high-tech start-up based in East-Germany and Silicon Valley, and EADS with headquarters in Germany and French (both organizational) and Netherlands (registered).
} 


\subsubsection{Media slant: dependent variables}

Our approach to measuring the slant of the newspaper is similar to the method used by Eisensee and Strömberg (2007), who compare the media coverage of disasters, depending on the persons killed and the region where it occurs. We compare and explain the coverage per job lost, depending on the ownership of the firm. To be precise, we use:

$$
w_{i}=\frac{\text { Words about downsizing }}{\text { Jobs lost }}
$$

where $w_{i}$ is the number of words about downsizing summed over all articles reporting on the downsizing case $i$, divided by the number of jobs shed in this event. A second measure is:

$$
a_{i}=\frac{\text { Articles about downsizing }}{\text { Jobs lost } / 1,000}
$$

where $a_{i}$ is the number of articles about downsizing in the newspaper in a downsizing case $i$, divided by the number of jobs shed in this event, scaled down by $1 / 1,000$.

\section{TABLE 4 ABOUT HERE}

Panel A of Table 4 compares the dependent variables for domestic and foreign firms. The first column reports the number of observations, the second the average $w_{i}$ of all downsizing cases. The corresponding standard deviations are in parenthesis. The third column show the same for $a_{i}$. As one can see, the media coverage (measured in words) for foreign firms that downsize is more than twice as large as for domestic firms, and there are more than $50 \%$ more articles per jobs shed written on foreign firms that downsize than domestic ones.

Panel B compares the size of articles on downsizing events, and the number of words spent on downsizing (rather than on other news related to the firm). An interesting pattern emerges: while the number of words in any article is the same for domestic and foreign firms (388.96 to 388.61, arguably due to layout reasons), on average in articles on downsizing by foreign firms 19\% more words are spent on downsizing than in articles on domestic firms. Articles on foreign firms have the same size, but more words are devoted to downsizing.

Table 4 makes clear that the raw media slant against foreign firms is caused by two effects: more articles are written about it, and in each given article more words are written about downsizing, rather than other aspects of the firm.

\subsubsection{Newspaper technology}

Valentino Larcinese, Puglisi and Snyder (2011) have discussed the possible impact of the newspaper section on media slant. To exclude that the slant is a technical artifact, we investigate in which section of the newspaper the article appears for foreign and domestic 
firms. We distinguish between stories on the front page, political section, business section, finance section and other sections.

\section{TABLE 5 ABOUT HERE}

From Panel A of Table 5 it can be seen that the distribution of articles about foreign firms is roughly the same as for domestic ones. More articles about downsizing of domestic firms appear in the finance section, which is in line with the well-documented home bias of financial investors (e.g. by Joshua Coval and Tobias Moskowitz, 1999; Gur Huberman, 2001; Holger Wolf, 2000). Panel B presents the average number of words in the whole articles and Panel $\mathrm{C}$ the average number of words about downsizing in those articles, distinguishing between the different sections of the newspaper. The average numbers are roughly the same for domestic and foreign firms in all sections.

\section{TABLE 6 ABOUT HERE}

Because the number of pages in the newspaper varies between 37.5 and 39.5 on average on different weekdays, we checked whether those differences could drive our results. Table 6 shows the number of articles, and the average number of words reporting about downsizing in those articles, distinguishing between the different weekdays. As is clear from the Tables, the relationship between articles reporting about downsizing of foreign and domestic firms is roughly the same on all days of the week. In addition, articles about downsizing of foreign firms have on average more words on a job shed than articles on downsizing of domestic firms at all days. We are thus quite confident that technical reasons cannot cause the observed raw media slant.

\section{Empirical specification and basic results}

\subsection{Quantitative media slant against foreign firms}

Our baseline OLS regressions are as follows:

$$
\begin{aligned}
& w_{i}=\beta_{0}+\beta_{1} \text { foreign }_{i t}+\beta_{2} \text { industry }_{i}+\beta_{3} \text { time }_{i}+\varepsilon_{i, t} \\
& a_{i}=\beta_{0}+\beta_{1} \text { foreign }_{i}+\beta_{2} \text { industry }_{i}+\beta_{3} \text { time }_{i}+\varepsilon_{i, t}
\end{aligned}
$$

Here, $w_{i}$ is the summed number of words about downsizing on the downsizing case $i$ divided by the number of jobs shed. In the same spirit, $a_{i}$ is the summed number of articles about downsizing in case $i$ divided by the number of job lost in the event, multiplied by 1,000. Ownership is captured by foreign dummy variables, and an industry dummy is used in most of the specifications. We use robust standard errors in almost all of our regressions; using clustered standard errors on the sector level does not change the results. 
We also take possible time effects into account. There are several ways to control for the effects of time, because different articles on a downsizing event appear at different points of time. The temporal structure in most downsizing cases looks as follows. First, one or a few articles refer to rumors and advance notices. This is followed by the official announcement and background reports some days later. A few days later, additional background reports appear, followed by an article when downsizing is completed, usually some months later. Thus, in our dataset, the bulk of articles on a downsizing case appear in a short window of time: in 450 (roughly $70 \%$ ) of the downsizing cases at least $75 \%$ of the articles and words about downsizing appear in one month; in 120 cases in two, and in 43 cases in three months. Only in 38 cases $75 \%$ of the media coverage occurred in a time span between 4 and 9 months. In the baseline regression, the time dummy is one for the months during which at least $75 \%$ of the words and articles have appeared, and zero for the months before and after.

\section{TABLE 7 ABOUT HERE}

Panel A of Table 7 presents the regression result with words on downsizing as the lefthand-side variable, both without and with time and industry dummies. In general, including the dummies improves the fit of the regressions substantially, but the magnitude of the difference in media coverage between domestic and foreign-owned firms remains stable, between 1.5 and 2. We have also used other definitions for the time variable, for instance, we set the time dummy to one for the year when $75 \%$ or more of the articles and words appeared, or to one for the month where the first article appears. None of this changes the main results in a qualitative way. (Results are in the web appendix, Table B.) Table 7 also shows that adding absolute and relative magnitude of the downsizing event (that is, jobs shed/total number of workers employed by the firm in Germany before downsizing) does not change the point estimate substantially.

\section{TABLE 8 ABOUT HERE}

Panel B reports the results for the regressions with articles per 1,000 jobs shed as lefthand-side variable. In all these regressions the qualitative results are quite similar. Because our regression is based on the assumption of linear effects, we rerun our baseline regression using logarithm of our dependent variables and include the total number of jobs shed and total employment of the firm before downsizing (both measured in logs). As shown in Table 8 the main results are also the same. ${ }^{26}$

\footnotetext{
${ }^{26}$ In Figure A in the web appendix we also present a scatterplot of words/articles and the number of jobs lost within domestic and foreign firms which shows that the functional forms looks quite linear.
} 
The fact that the point estimates for the foreign ownership dummy are positive and economically significant for both dependent variables shows that the total media slant works through two channels. To see this, consider columns (1a) and (1b) of Table 7. While foreign firms receive $100 \%$ more words for each job shed, there are roughly $50 \%(8.1 / 15.4)$ more articles on downsizing by foreign firms. Hence, more articles are written on downsizing by foreign firms, and in each article, more words are written on downsizing. Notice, however, that the dependent variables "words" incorporates both of these channels, because it accounts for the total slant. Hence, to save on tables, we only report the results on "words"; results on articles as left-hand-side variable are summarized in the web appendix.

\subsection{Qualitative media slant against foreign firms}

Robert Entman (1991) studies how two similar events were covered in U.S. media. One was the Soviet military's downing of a Korean passenger plane in the early 1980s; the other the U.S. military's downing of an Iranian passenger plane in the late 1980s. The foreign downing was described as "Murder in the sky", "Shoot to kill", the other as a technical problem.

To investigate whether Die Welt also describes the downsizing of domestic and foreign firms in different ways, one needs an evaluation of the connotation for each article. Usually, qualitative aspects are hard to measure, but we received access to data by Media Tenor, a Switzerland-based media consulting company. The company employs more than 120 employees who read several newspapers each day and record all articles where first, the name of any company is mentioned and second, five or more sentences report about the company. For each article they also record whether the article reports in a positive $(+1)$, neutral $(0)$ or negative (-1) way. The company uses the following algorithm to evaluate each article. They first identify which adjectives are used in the article and whether those are rather positive or rather negative. Second, they identify whether the context of an article is consistent with the adjective-based evaluation. In case of contradiction, the evaluation is based on the context. To make sure that all employees of Media Tenor evaluate the articles in the same way, they get three months of training, before working for the company. Moreover, once per month, the management of Media Tenor randomly selects some articles and checks whether the articles have been coded in the right way. Employees' wages are based on the result of this check.

\section{FIGURE 1 ABOUT HERE}

For Die Welt, Media Tenor recorded all articles between August 2001 and September 2007 that classified the criteria mentioned above. We matched this dataset with our database. In total, we get a qualitative evaluation for 2,109 of the 5,172 articles in our database. Figure 
1 provides an overview of the distribution of the articles, by ownership and evaluation. In total, the 1,346 articles reporting about downsizing of domestic firms get an average evaluation of -0.215 (s.d. 0.678). However, the 763 downsizing articles reporting about foreign firms get an average evaluation of -0.307 (s.d. 0.644). This difference (roughly 50\%) is significant according to a t-test (two-sided, p-value: 0.001), and of a similar magnitude as the quantitative effects.

\section{FIGURE 2 ABOUT HERE}

To make sure that we do capture a slant against downsizing by foreign firms, and not against foreign firms in general, we carried out the following analysis. We collected all articles on the 424 foreign and domestic firms that downsized in our data set. Then, we checked Media Tenor's qualitative evaluations of all articles on these firms which are not related to downsizing. In total there are 34,554 articles reporting about our domestic firms and 10,351 articles about foreign firms. Articles about domestic firms receive an average evaluation of 0.012 (s.d. 0.572), foreign firms of 0.015 (s.d. 0.590). As indicated in Figure 2 this difference is far away from being significant (two-sided t-test, p-value: 0.667). An interesting additional fact is that domestic firms receive more media attention in general (by a factor of three). This makes our result that Die Welt publishes more articles about foreign firms' downsizing even more striking. ${ }^{27}$

We have identified an additional fact in line with our story on slant against foreign firms that downsize. We looked at all reports in LexisNexis on job creation, or "upsizing", distinguishing foreign versus domestic firms. Using a similar algorithm as for downsizing, we ended up with 451 articles about 76 companies and 100 upsizing-events. ${ }^{28}$

\section{TABLE 9 ABOUT HERE}

A share of $67 \%$ of the upsizing cases report on domestic firms, which is the same share as for downsizing cases. Comparing the number of words in the paragraphs in which at least one synonym for upsizing appeared, we find no statistically significant difference in reporting on foreign versus domestic firms (134.66 to 125.27, with a two-sided t-test, p-value: 0.428). The average number of articles per upsizing case is higher for domestic compared to foreign firms (5.34 to 2.85), but, again, the difference is not significant (two sided t-test, p-

\footnotetext{
${ }^{27}$ Using LexisNexis, we also counted all articles that mention the three leading domestic firms in each sector in other contexts, such as strategy, new products, new management etc. We compared their media coverage with the one of the three leading foreign-owned competitors, for instance, Siemens versus Alstom, VW versus Ford and found that 2.7 times more articles were written on the three largest German firms in each sector than on their foreign counterparts (see web appendix, Table C).

${ }^{28}$ The upsizing company with the lowest share of a foreign block-holder is N3 Engine Overhaul Services, a joint venture owned 50:50 by the German Lufthansa and the British Rolls-Royce.
} 
value: 0.445 ). As shown in Table 9, a comparison of the average number of words per created new job (column 2) and number of articles per 1,000 created new jobs (column 3) is roughly the same. In OLS regressions along the lines of the ones used for downsizing, with the dependent variables words per job created and articles per 1,000 jobs created, the foreign dummy as independent variable is far away from significant in any specification we tried (web appendix, Table D).

\section{Robustness checks}

In this section, we address (i) measurement issues concerning the distinction between foreign and domestic firms; (ii) sources of endogeneity, like sorting of foreign versus domestic firms into different regions and sectors, and into local labor markets with different unemployment rates; (iii) omitted variables about capital structure and ownership, and the country of origin of owners. We also investigate whether foreign firms carry out downsizing in different ways or with different reasons than domestic firms, another source of omitted-variable bias.

\subsection{Definition of variables: foreign versus domestic ownership}

The classification of domestic and foreign firms may, in principle, be prone to measurement errors, as it is not always evident whether a firm should be treated as foreign or domestic firm. We have hence experimented with a number of modified samples, each of which is generated by an exclusion or inclusion of a specific type of firm. First, we ran the baseline regression excluding all downsizing cases in which foreign investors hold less than $75 \%$, because German law gives shareholders with $75 \%$ or more of the equity complete control over the company. Second, we excluded cases in which foreign block-holders hold less than $100 \%$ of the equity. Third, we included hybrid firms with changing ownership during the period of downsizing and shared or unclear control rights. Fourth, we included firms with two headquarters. Finally, we excluded cases in which domestic firms have no substantial German blockholder. In none of the regressions (web appendix, Table E), we found the parameter to be affected substantially. The foreign dummy is always positive and statistically highly significant. $^{29}$

\footnotetext{
${ }^{29} \mathrm{We}$ also checked whether it matters for the result to treat different downsizing events of a firm independently, as we have done. We thus re-ran our baseline regression summing up the number of words (articles) about downsizing on firm level rather than on downsizing event level. We also ran our regressions including a firm-dummy for each firm with two or more downsizing events. In addition, we controlled for newsworthiness of the companies using Alexander Dyck, Natalya Volchkova and Luigi Zingales's (2008) approach. Table F in the web appendix shows that the main qualitative results are the same in all regressions.
} 
The case of firms that change ownership from foreign to domestic (or vice versa) and downsize under both owners, provide an additional interesting insight. While we have only 13 of such firms in our data set, the descriptive statistics show that when owned by domestic owners, the newspaper writes 1.84 (s.d. 1.31) words per job shed and 15.41 (s.d. 13.10) articles per 1,000 jobs lost. If the same firm is owned by foreign investors, media attention increases to 7.37 (s.d. 6.29) words per job, and 33.64 (s.d. 26.90) articles per 1,000 jobs lost.

Readers may not be aware of the origin of the firm. In quite a few cases, the name of the firm may sound German, although the origin of the company is foreign, e.g. the U.S. company Kraft. Here, it is useful to look at those articles in which the origin of the owner is explicitly mentioned, which is the case in $47.5 \%$ of the articles reporting about foreign firms. Excluding the downsizing cases where the origin of the firm is mentioned in less than $50 \%$ or $25 \%$ of the articles, generates quite similar results as the baseline estimates (web appendix, Table G).

\subsection{Self-selection of foreign firms: region, sector, size, unemployment}

Estimating the causal effect of company ownership on media coverage about downsizing poses a problem of possible endogeneity of foreign ownership. Foreign owners may systematically select firms that are different from domestic ones, for instance they may sort into different industries or different regions. We also know from the descriptive statistics that the average foreign firm employs less workers in Germany than the average domestic firm. If these characteristics attract more interest from the media in general, they also do so when firms downsize, and our estimates would be biased. To control for these characteristics, we use propensity score matching regressions.

In line with Rosenbaum and Rubin (1983), we use the algorithms by Becker and Ichino (2002). In a first step, we calculate the probability of a firm being foreign with a logit model, using a dummy for the region (Bundesland) where the firm is headquartered in Germany, a dummy for each industry, and the number of employees in Germany as a continuous variable. In a second step, we use the Nearest-Neighbor matching procedure. ${ }^{30}$

\section{TABLE 10 ABOUT HERE}

Panel A in Table 10 presents the average treatment effect on the treated: The estimated coefficient is 2.057 and 2.267 and highly significant in both regressions. Thus, the coefficient is similar as in our OLS baseline regression. Running estimations where we exclude all observations with a propensity score less than 0.1 or greater than 0.9 (Panel B), as suggested

\footnotetext{
${ }^{30}$ We also used Kernel as matching method. The main results remain qualitatively the same.
} 
by Richard Crump, Joseph Hotz, Guido Imbens and Oscar Mitnik (2009), leads to similar results. Given our controls, there is hence no evidence that foreign firms in our sample have systematic characteristics that differ from domestic companies.

\section{TABLE 11, FIGURE 3 ABOUT HERE}

German workers are relatively immobile. Local labor markets have quite different degrees of unemployment, and the local unemployment rates develop differently over time. For a number of reasons, media attention for downsizing is likely to depend on the local unemployment rate. For example, Louis Jacobson, Robert LaLonde and Daniel Sullivan (1993) have shown that workers' costs of losing their jobs are higher when the local unemployment rate is high, which would provide a rationale for media to report more about this. We hence split our sample of firms in quintiles, based on the quarterly local unemployment rate (broken down by town and district). As shown in column (3) and (4) of Table 11, the distribution of domestic and foreign firms is roughly the same across quintiles. This suggests that there is no self-selection of foreign or domestic firms in regions plagued by high unemployment rates. The Table offers another interesting observation depicted in Figure 3: there is no pattern regarding the correlation of unemployment quintile and media coverage per job shed for domestic firms. However, for foreign firms when moving from the first to the fifth quintile, media coverage per job shed increases from 3.07 to 4.63 .

\subsection{Omitted variables: capital structure, ownership, country of origin}

We classify foreign and domestic companies into five categories: publicly listed, privately owned, private-equity, government owned and multiple/other owners when the company is owned by a foundation or large parts of the firm are owned by different kind of owners. In the regression we interact these classifications with domestic and foreign ownership.

\section{TABLE 12 ABOUT HERE}

The coefficients of foreign, publicly listed, foreign, private equity and foreign, privately owned in Table 12 are positive, while the respective coefficients for domestic are not significant. Hence, the general tendency of slant against foreign owners is confirmed, and certain ownership forms receive more attention when the owner is foreign.

It is also possible that the bias is against owners from specific countries. For instance, Anglo-Saxon countries are perceived to represent a "free market economy" which may have negative connotations, compared to the more positively connotated "social" (or Rhineland) market economies of Germany, France, Austria or Belgium. 
For reasons of small samples, we cannot control for each country separately. Hence, we created the following regional variables: Continental Europe, U.K./Ireland, North America, Japan, others. The estimated coefficients in Table 13 are positive ranging from 1.395 for North America, 1.547 for Continental Europe, 1.998 for Japan to 2.319 for U.K./Ireland. Except for Japan (p-value: 0.157) and others, the coefficients are significant.

\subsection{Do foreign firms downsize in different ways or for different reasons?}

Becker and Mündler (2010) have shown that MNEs behave differently at the extensive margin, i.e., creating new plants or closing existing ones. Media slant could then be explained as a bias against closures, not foreigners. Our data set allows us to control for plant closures. Following Marianne Bertrand, Francis Kramarz, Antoinette Schoar and David Thesmar (2004), we distinguish between firms that close and firms that do not close an establishment.

\section{TABLE 14, 15 ABOUT HERE}

From the descriptive statistics in Table 14 it becomes clear that establishment closures are roughly occurring with the same frequency for domestic and foreign firms (around $25 \%$ for domestic and $30 \%$ for foreign firms), but that closures do not seem to drive the slant. If anything, establishment closures of both foreign and domestic firms receive less media attention. The regressions (shown in Table 15) indeed do not find any effect that would support the conjecture that media slant is about closures rather than on foreign owners.

\section{TABLE 16 ABOUT HERE}

We also run similar propensity score estimations as in Chapter 5.2 for several characteristics of the downsizing event, using a dummy for establishment closure, the total number of jobs shed, the average local unemployment rate, and the lag between the beginning and completion date of downsizing according to Die Welt as controls in our estimation. The coefficients for foreign ownership in Table 16 are positive significant in all estimations. ${ }^{31}$

Foreign firms may tend to shed jobs for other reasons than domestic firms. We augment our baseline model with the reasons given for downsizing in the media and press communiqués of the respective company. The list includes state intervention, offshoring, insolvency, $M \& A$, other reasons, and multiple reasons. The baseline is no reasons given.

\section{TABLE 17 ABOUT HERE}

The regressions in Table 17 show a similar effect of foreign as before. The coefficient of state intervention is positive and significant; none of the other variables are statistically

\footnotetext{
${ }^{31}$ We also run our baseline regression including a dummy for firms which according to the newspaper reports had received subsidies. However we only had 18 such cases and the results did not change much; neither did the inclusion of an interaction term between foreign and subsidies affect the results.
} 
significant. Distinguishing $M \& A$ with acquiring firms that are headquartered in Germany (M\&A domestic) from the ones headquartered in foreign countries (M\&A foreign) shows another interesting pattern. $M \& A$ domestic is insignificant in the regression, but $M \& A$ foreign is positive and significant, i.e. downsizing related to mergers and acquisitions attracts more media attention if the acquiring firms are foreign owned. ${ }^{32}$

\section{TABLE 18 ABOUT HERE}

From the above, it is clear that slant cannot be explained by the ways and reasons of foreign firms' downsizing. It is still possible that foreign firms do not communicate their downsizing programs in the same way German firms do, but there are two arguments against this. First, around $1 / 3$ of the foreign firms in our dataset have owned plants in Germany for 50 years or more (for instance GM/Opel, and Ford). Second, neither domestic nor foreign SMEs are likely to invest a lot in $\mathrm{PR} .{ }^{33}$ Running our baseline regressions on firms employing 500 or less workers in Germany shows that the foreign coefficient is positive (Table 18), significant and even larger than in the baseline regression with the full sample.

\section{Channels of the slant}

The preceding sections documented a strong slant against foreign owners, and established its robustness. In this section, we investigate which theories are most likely to explain these facts.

\subsection{News process, perception}

The process through which an event becomes news entails the following stages: the downsizing action or communiqué of a firm is received by a news agency, the German Press Agency DPA, which informs all newspapers about downsizing news. Thus, as argued by Gentzkow and Shapiro (2006) and Mullainathan and Shleifer (2005), newspapers observe the same signal. Each newspaper then decides whether and how to report on the downsizing, and how much space to allocate to it.

Using the same algorithm as for Die Welt, we checked the coverage about the first 50 downsizing cases of domestic and foreign firms (sorted by alphabet) in our dataset (to analyze the entire data set would be very resource-intensive). The agency writes 2.71 (s.d. 2.56) words per job shed and 17.61 (s.d. 21.14) articles per 1,000 jobs lost when the firm is owned by a German blockholder; for foreign-owned firms it is 1.95 (s.d. 2.40) words per job shed and

\footnotetext{
${ }^{32}$ Examples could be the heated public discussions in Germany when the British Vodafone Airtouch acquired German Mannesmann in 2001 or the Spanish ACS the German Hochtief in 2010/2011.

${ }^{33}$ For instance, David Solomon (forthcoming) shows that it is mostly large enterprises that employ investor relation firms to communicate good or bad news.
} 
12.58 articles per 1,000 jobs lost. ${ }^{34} \mathrm{DPA}$ actually reports less on downsizing by foreign firms, which makes the slant we document even more significant.

\subsection{Advertiser influence}

Matthew Ellman and Fabrizio Germano (2009), Gambaro and Puglisi (2010) and Reuter and Zitzewitz (2006) argue that advertisers' influence can cause slant. Domestic firms in our dataset could be placing more advertising than foreign ones. As a result, domestic firms could put pressure on editors or journalists to provide favorable coverage (e.g. write less about downsizing activities). ${ }^{35}$ However, as already shown in Table 18, the media slant against foreign firms is even larger for SMEs. Because neither domestic nor foreign SMEs invest a lot in advertising in main national newspapers, this fact is not in line with a story that advertisers are the main force explaining the slant.

\section{TABLE 19 ABOUT HERE}

As a second analysis, we randomly chose five months (November 2002, July 2005, September 2006, May 2007, May 2008), and record all firms that place advertisements in Die Welt in this period. A total of 42 out of the 290 advertisers we record did shed jobs in Germany in the period of observation. As shown in Table 19, neither the inclusion of a dummy capturing whether a downsizing firm is placing advertising nor an interaction term between Advertiser and foreign/domestic affect the results. Thus favoring domestic advertisers does not seem to be relevant in our case.

\subsection{Journalists’ influence}

Baron (2006) has shown that media bias can be caused by a supply effect. Certain journalists may have preferences for certain news. They may be interested in convincing the public that foreign firms are "bad" for domestic workers. The newspaper may allow them to report in a biased way, because this makes it possible to retain the journalist and/or to cut wage costs.

\section{TABLE 20 ABOUT HERE}

The hypothesis is investigated by first dividing all articles in two categories: those where the author signs the article (a total of 3,291 articles), and those where the author is

\footnotetext{
${ }^{34}$ Seven of the downsizing firms received no coverage by the DPA at all. We exclude those firms here. Including them (with "0" words per job shed/"0" articles per 1,000 jobs lost) results in 2.17 (s.d. 2.54) words per job shed and 14.09 (s.d. 20.14) articles per 1,000 jobs lost for domestic firms and 1.79 (s.d. 2.36) and 11.57 (s.d. 14.97) articles per 1,000 jobs lost for foreign firms.

${ }^{35}$ Notice that this is an argument similar to political economy explanations of media bias, where journalists report favorably about certain policies, because they need to maintain a good relationship to politicians who provide them with privileged material.
} 
unknown (a total of 1,881 articles that are either taken from news agencies, from freelancers or junior journalists). Table 20 shows that authors who sign their article write longer articles, but the general bias is the same. We also distinguish authors that have written large numbers of articles on downsizing; 220 (out of 271) authors wrote 10 or less articles, only 15 wrote more than 50 articles, one of them 350. Excluding authors who have written more than 50 articles does not affect the results, which goes against the idea that the bias could be driven by the fixed effects of a small group of biased authors. ${ }^{36}$

\section{TABLE 21 ABOUT HERE}

The results of a further robustness check are shown in Table 21. We excluded all downsizing cases for which $50 \%$ or more of the articles were written by journalists with 50 or more articles. We also tried a threshold of $30 \%$. None of this changes the results in a substantial way. The slant is hence not driven by „some“ biased journalists, but we cannot exclude that journalists are in general biased. ${ }^{37}$

\subsection{Differentiation: Evidence from six other newspapers}

A number of theoretical papers, in particular, Mullainathan and Shleifer (2005), and Anderson and MacLaren (2012) have argued that newspapers are catering to the beliefs of their readership. Gentzkow and Shapiro (2010) have presented empirical evidence. But, why would a business-friendly newspaper like Die Welt slant reports about foreign owners? There are two possible interpretations. One is that a conservative business-friendly readership may be xenophobic for reasons beyond a simple economic cost-benefit appraisal. Another one is that in terms of beliefs about foreign owners everyone may be biased.

This question motivated us to generate another data set in which we take the positioning of all national quality newspapers in the German market as given, and measure the slant with which news about foreign-owner downsizing is reported. The data set makes it possible to verify (i) whether all national quality newspapers in Germany slant their reports and (ii) whether there is an identifiable pattern of how the general political orientation of a newspaper correlates with the magnitude of the slant.

While there is no recent scientific study on the positioning of the newspapers on the German market, the task of determining their general political orientation is not too

\footnotetext{
${ }^{36}$ In most cases single authors specialize on one or more industries. Thus, industry variables in our regression are somehow proxies for those authors.

${ }^{37}$ To exclude that journalists write more about downsizing in Hamburg and Berlin (headquarters of Die Welt and the Axel Springer Publishing House), as a large portion of them (and large parts of the readership) might live there, we run our baseline including a dummy for jobs shed in the two towns. As shown in Table $\mathrm{T}$ in the web appendix, the main qualitative results are the same.
} 
complicated. First, the two business newspapers, Handelsblatt and Financial Times Deutschland (FTD) can be assumed to be relatively a-political, as their most important task is conveying news as an input into business and investment decisions. Moreover, FTD was partially owned by Pearson, a British publishing house who would certainly not want to influence the newspaper against globalization.

From right to left, German quality newspapers are positioned as follows. First, there are the right-of-center Die Welt and Frankfurter Allgemeine Zeitung (FAZ). We have already discussed the orientation of Die Welt, which is majority-owned by the Springer family, a famously Christian-conservative family, close to the conservative CDU. Similarly, the FAZ is a conservative and what Germans would call "economically liberal" 38 newspaper and recently one of the editors of FAZ, Werner D'Inka, was quoted that there "is nothing wrong with this label; it will stay like this". ${ }^{39}$ A study of the 1990s also showed that a large majority of the FAZ readers are CDU voters (Wolfgang Donsbach, 1991).

Moving to the left we have the Süddeutsche Zeitung (SZ) whose orientation is readily identified by the mission statement that expresses the newspaper's commitment to a "society based on free, social and democratic principles". SZ is hence often described as "moderately left wing". ${ }^{40}$ The readers of SZ feature a majority of social democrats and greens (Donsbach, 1991). Frankfurter Rundschau (FR) has a long-standing left-wing orientation. In 2005, FR was bailed out by the $S P D$, the german social-democrat party. Until today the social democratic party maintains a strong stake in the newspaper. Ute Volkmann (2006) compares the commentaries of FR with other newspapers and comes to the conclusion that there is no other quality newspaper with a comparably strong affinity to a political party. The general orientation as a newspaper close to trade unions has not changed over decades. The newspaper has also been advocating state interventions and collective agreements between trade unions, and employer associations, mediated by state institutions.

Finally, Die Tageszeitung (TAZ), the smallest quality newspaper, has the strongest leftwing orientation, which is not only manifested in its mission statement but also reflected in the ownership form. Since its launch in 1978, TAZ has been owned by a cooperative; it was founded by representatives of the 1968 generation and defines its mission as follows: "TAZ is committed to a critical public opinion. It supports the defense and development of human

\footnotetext{
${ }^{38}$ Not to be mistaken with the term "liberal" in the U.S.; "liberal" in Germany is usually associated with beliefs in a free rather than a regulated market economy.

${ }^{39} \mathrm{http}: / / \mathrm{www} . d r a d i o . d e / d l f / s e n d u n g e n / m a r k t u n d m e d i e n / 677966 /$

${ }^{40} \mathrm{http} / / / \mathrm{www}$.goethe.de/wis/med/prj/dzz/tag/sz/deindex.htm
} 
rights and is the channel for those interests that otherwise would not get the attention of those in power." 41

\section{TABLE 22 ABOUT HERE}

To investigate the media slant in these newspapers, we randomly chose five months from our period of observation ${ }^{42}$ and carried out the same search algorithm as the one used for the initial data set. Notice, however, that we cannot investigate whether during those five months, the newspapers publish more articles on each downsizing case (as was the case in the initial data set), because the five months are disjunct, and the publishing sequence of articles may be quite different in each newspaper. However, we can measure whether the average number of words on downsizing by foreign versus domestic firms shows any patterns across newspapers.

The descriptive results (see Panel B of Table 22) are striking. All newspapers have a slant in the same direction, even the business papers. Mullainathan and Shleifer (2005) distinguished topics on which people have heterogeneous beliefs from those on which beliefs are homogeneous, and argued that foreign policy is a good example for the latter. The negative beliefs about foreign owners' impact on employment seem to be equally homogeneous.

The magnitude of the slant, however, is quite different and shows a clear pattern. Business newspapers FTD spends on average 1.07, Handelsblatt 1.15 times more words per article on foreign firms' downsizing. The ratio of Die Welt is 1.15 , consistent with the initial dataset (from which we sampled five months). The FAZ, also right-of-the-center, has a ratio of 1.17. SZ and FR, both left of center, have a ratio of 1.24 and 1.25 , respectively. The leftwing TAZ has the strongest bias with a ratio of 1.27 . We cannot run regressions with the data we have and collecting a data set of comparable size to the one we have for Die Welt for all newspapers is (almost) impossible. Nonetheless we would argue that the evidence for a pattern in which the magnitude of slant increases from right to left is quite compelling.

\subsection{Owner influence}

There is yet another alternative explanation for the slant: newspaper owners could be biased (as studied by Gentzkow and Shapiro, 2010, who find no evidence). However, the newspapers we look at are owned by quite different owners. The FAZ is owned by a foundation (FAZ-

\footnotetext{
${ }^{41} \mathrm{http}: / / \mathrm{www} \cdot$ taz.de/6/redaktionsstatut/

${ }^{42}$ November 2002, July 2005, September 2006, May 2007, May 2008.
} 
Stiftung), TAZ by a cooperative, Welt and the Handelsblatt (Holtzbrinck family) by families. It is hardly conceivable that all of these owners should be biased in the same direction as they are sophisticated players with different political agendas and commercial interests.

To lend support to our claim that owner bias cannot explain our evidence, we use the fact that three newspapers changed their owners in our period of observation, all because of severe financial difficulties. The FR was majority-owned by a foundation until 05/2004 (KarlGerold-Stiftung), by the SPD until 07/2006 and afterwards by the family DuMont Schauberg. The SZ was owned by several families, and 03/2008 acquired by the entrepreneur Dieter Straub and several other families. FTD initially was a 50-50 joint venture of Bertelsmann and the U.K. based Pearson Group; in January 2008 Bertelsmann acquired Pearson's 50\% share.

To investigate whether the slant in these three newspapers is the same under different owners, we further expand our dataset from the previous Chapter. In addition to the five months for which we have identified all articles about downsizing, we randomly choose several months more until we ended up with three months for each owner of each newspaper. As shown in Table $U$ in the web appendix, the owner changes have no substantial impact on the slant for any of the newspapers. We conclude that substantial owner bias is unlikely.

\section{Concluding remarks}

We have established a robust fact about media reports about downsizing by foreign owners in Germany. Although Germany is a leading export country, second only to China, and the German population is among the most globalization friendly ones, for any job shed, a firm with substantial foreign ownership receives twice as much media attention when it downsizes than a comparable domestic firm. We have controlled for any conceivable omitted variable bias, and different stories of self-selection of foreign owners into regions or industries that could attract negative attention, but our results are very robust to these checks. The slant is present in all national quality newspapers; its magnitude increases the further a newspaper is positioned to the left. Quantitative slant is accompanied by qualitative slant.

Newspapers and other media have an important role to play in transmitting news to people, and these news and the information they contain will shape their economic decisions. The slant we identify, quite likely caused by the attempt of newspapers to please their readership, may have severe economic consequences and cause substantial obstacles to foreign direct investment. To the extent that the somewhat negative a priori belief of the population about the costs of globalization gets strengthened by the media, foreign companies 
may fear to be punished for activities domestic firms would barely be noticed for. The case studies we presented make clear that the potential penalty foreign firms must pay when downsizing can be large. The implications for foreign direct investment in Germany could be drastic. Foreign owners may price in the potential penalty caused by slanted media reports. Some firms may not find owners because of the media slant, in the case of others, the cash raised may be lower in the case of foreign acquisitions, and foreign owners may try to avoid firms that produce final goods, rather than intermediary goods, because the penalty is induced by the media, but ultimately carried out by consumers, as the case of Nokia illustrates. 


\section{References}

Anderson, Simon P. and John McLaren (2012), "Media Mergers and Media Bias with Rational Consumers", Journal of European Economic Association, Vol. 10, No. 4, pp. 831859.

Baumol, William J., Alan S. Blinder and Edward Wolff (2003), Downsizing in America Reality, Causes, and Consequences, New York: The Russell Sage Foundation.

Baron, David P. (2006), "Persistent Media Bias", Journal of Public Economics, Vol. 90, No. 1-2, pp.1-36.

Becker, Sascha and Andrea Ichino (2002), "Estimation of Average Treatment Effects Based on Propensity Score”, The Stata Journal, Vol. 2, No. 4, pp. 358-377.

Becker, Sascha and Marc-Andreas Muendler (2010), "Margins of Multinational Labor Substitution”, American Economic Review, Vol. 100, No. 5, pp. 1999-2030.

Bertrand, Marianne, Francis Kramarz, Antoinette Schoar and David Thesmar (2004), "Politically Connected CEOs and Corporate Outcomes: Evidence from France", Working Paper.

Besley, Timothy and Robin S. L. Burgess (2002), "The Political Economy of Government Responsiveness: Theory and Evidence from India”, Quarterly Journal of Economics, Vol. 117, No. 4, pp. 1415-1451.

Besley, Timothy and Andrea Prat (2006), "Handcuffs of the Grabbing Hand? Media Capture and Government Accountability", American Economic Review, Vol. 96, No. 3, pp. $720-736$.

Borrmann, Christine, Rolf Jungnickel and Dietmar Keller (2003), Auslandskontrollierte Unternehmen - ein Gewinn für den nationalen Arbeitsmarkt?, Baden-Baden: Nomos Verlag.

Braconier, Henrik and Karolina Ekholm (2000), "Swedish Multinationals and Competition from High- and Low-Wage Locations", Review of International Economics, Vol. 8, No. 3, pp. 448-461.

Buch, Claudia M. and Alexander Lipponer (2010), "Volatile Multinationals? Evidence from the Labor Demand of German Firms", Labor Economics, Vol. 17, No. 2, pp. 345-353.

Coval, Joshua and Tobias J. Moskowitz (1999), "Home Bias at Home: Local Equity Preferences in Domestic Portfolios", Journal of Finance, Vol. 54, No. 6, pp. 2045-2073.

Crump, Richard K., Joseph Hotz, Guido Imbens and Oscar A. Mitnik (2009), "Dealing with limited overlap in estimation of average treatment effects", Biometrika, Vol. 96, No.1, pp. 187-199.

DellaVigna, Stefano and Ethan Kaplan (2007), “The Fox News Effect: Media Bias and Voting”, Quarterly Journal of Economics, Vol. 122, No. 3, pp. 1187-1234. 
Donsbach, Wolfgang (1991), Medienwirkung trotz Selektion - Einflussfaktoren auf die Zuwendung zu Zeitungsinhalten, Köln and Weimar: Böhlau Verlag.

Durante, Ruben and Brian Knight (2012), "Partisan Control, Media Bias, and Viewer Responses: Evidence from Berlusconi's Italy”, Journal of European Economic Association, Vol. 10, No. 3, pp. 451-481.

Dyck, Alexander, Natalya Volchkova and Luigi Zingales (2008), "The Corporate Governance Role of the Media: Evidence from Russia", Journal of Finance, Vol. 63, No. 3, pp. 1093-1135.

Entman, Robert M. (1991), "Framing U.S. Coverage of International News: Contrasts n Narratives of the KAL and Iran Air Incidents", Journal of Communication, Vol. 41, No. 4, pp. $6-27$.

Eisensee, Thomas and David Strömberg (2007), "News Droughts, News Floods, and U.S. Disaster Relief”, Quarterly Journal of Economics, Vol. 122, No. 2, pp. 693-728.

Ellman, Matthew and Fabrizio Germano (2009), "What Do the Papers Sell? A Model of Advertising and Media Bias”, Economic Journal, Vol. 119, No. 537, pp. 680-704.

Enikolopov, Ruben, Maria Petrova and Ekaterina V. Zhuravskaya (2011), "Media and Political Persuasion: Evidence from Russia", American Economic Review, Vol. 101, No. 7, pp. 3253-3285.

Gambaro, Marco and Riccardo Puglisi (2010), "What do ads buy? Daily Coverage of Listed Companies on the Italian Press", Working paper.

Gentzkow, Matthew and Jesse M. Shapiro (2006), "Media Bias and Reputation”, Journal of Political Economy, Vol. 114, No. 2, pp. 280-316.

Gentzkow, Matthew and Jesse M. Shapiro (2010), "What Drives Media Slant? Evidence from U.S. Daily Newspaper”, Econometrica, Vol. 78, No. 1, pp. 35-71.

Gentzkow, Matthew, Jesse M. Shapiro and Michael Sinkinson (2011), "The Effect of Newspaper Entry and Exit on Electoral Politics", American Economic Review, Vol. 101, No. 7, pp. 2980-3018.

George, Lisa (2007), "What's fit to print: The effect of ownership concentration on product variety in daily newspaper markets", Information Economics and Policy, Vol. 19, No. 3-4, pp. 285-303.

Greiner, Ben (2004), An Online Recruitment System for Economic Experiments, in: Kurt Kremer, Volker Macho, eds, Forschung und wissenschaftliches Rechnen 2003, GWDG Bericht 63 (Ges. für Wiss. Datenverarbeitung, Göttingen, Germany), pp. 79-93.

Groseclose, Timonthy and Jeffrey Milyo (2005), “A Measure of Media Bias”, Quarterly Journal of Economics, Vol. 120, No. 4, pp. 1191-1237. 
Huberman, Gur (2001), "Familiarity Breeds Investment", Review of Financial Studies, Vol. 14, No. 3, pp. 659-680.

Jacobson, Louis S., Robert J. LaLonde and Daniel G. Sullivan (1993), "Earnings Losses of Displaced Workers", American Economic Review, Vol. 83, No. 4, pp. 685-709.

Konings, Jozef and Alan Patrick Murphy (2006), "Do Multinational Enterprises Relocate Employment to Low-Wage Regions? Evidence from European Multinationals", Review of World Economics, Vol. 142, No. 2, pp. 267-286.

Larcinese, Valentino, Riccardo Puglisi and James M. Snyder, Jr. (2011), "Partisan Bias in Economic News: Evidence on the Agenda-Setting Behavior of U.S. Newspapers", Journal of Public Economics, Vol. 95, No. 9-10, pp. 1178-1189.

Marin, Dalia (2004), “A Nation of Poets and Thinkers' - Less so with Eastern Enlargement? Austria and Germany”, CEPR Discussion Paper 4358.

Mayda, Anna-Maria and Dani Rodrik (2005), "Why are some people (and countries) more protectionist than others?", European Economic Review, Vol. 49, No. 6, pp. 1393-1430.

McCombs, Maxwell E. and Donald L. Shaw (1972), "The Agenda-Setting Function of Mass Media”, Public Opinion Quarterly, Vol. 36, No. 2, pp. 176-187.

Mullainathan, Sendhil and Andrei Shleifer (2005), "The Market for News", American Economic Review, Vol. 95, No. 4, pp. 1031-1053.

Myers, Caitlin Knowles (2005), "Discrimination as a Competitive Device: The Case of Local Television News", IZA Discussion Paper No. 1802.

Navaretti, Giorgio Barba and Anthony J. Venables (2004), Multinational Firms in the World Economy, Princeton and Oxford: Princeton University Press.

Oberholzer-Gee, Felix and Joel Waldfogel (2009), "Media Markets and Localism: Does Local News en Espanol Boots Hispanic Voter Turnout?", American Economic Review, Vol. 99, No. 5, pp. 2120-2128.

Olken, Benjamin A. (2009), "Do Television and Radio Destroy Social Capital? Evidence from Indonesian Villages", American Economic Journal: Applied Economics, Vol. 1, No. 4, 2009, 1-33.

Puglisi, Riccardo (2011), "Being The New York Times: the Political Behaviour of a Newspaper", The B.E. Journal of Economic Analysis \& Policy, Vol. 11, No. 1, pp. 1-20.

Reuter, Jonathan and Eric Zitzewitz (2006), "Do Ads Influence Editors? Advertising and Bias in the Financial Media", Quarterly Journal of Economics, Vol. 121, No. 1, pp. 197-227.

Rosenbaum, Paul R. and Donald B. Rubin (1983), “The Central Role of Propensity Score in Observational Studies for Causal Effects”, Biometrika, Vol. 70, No. 1, pp. 41-55. 
Scheve, Kenneth F. and Matthew J. Slaughter (2006), "Public Opinion, International Economic Integration, and the Welfare State", pp.217-260 in Bardhan, Pranab, Samuel Bowles and Michael Wallerstein (eds.), Globalization and Egalitarian Redistribution. New York: Russell Sage Foundation.

Soltes, Eugene (2009), "News Dissemination and the Impact of the Business Press." Ph.D. diss., The University of Chicago Graduate School of Business.

Solomon, David (forthcoming), "Selective Publicity and Stock Prices”, Journal of Finance.

James M. Snyder and David Strömberg (2010), "Press Coverage and Political Accountability", Journal of Political Economy, Vol. 118, No. 2, pp. 355-408.

Strömberg, David (2004), "Radio's Impact on Public Spending", Quarterly Journal of Economics, Vol. 119, No. 1, pp. 189-221.

Sweeting, Andrew (2007), "Dynamic Product Repositioning in Differentiated Product Markets: The Case of Format Switching in the Commercial Radio Industry", NBER Working Paper.

Sweeting, Andrew (2010), "The effects of mergers on product positioning: evidence from the music radio industry”, RAND Journal of Economics, Vol. 41, No. 2, pp. 372-397.

Volkmann, Ute (2006), Legitime Ungleichheiten. Journalistische Deutungen vom „sozialdemokratischen Konsensus“ zum „Neoliberalismus“, Wiesbaden: Verlag für Sozialwissenschaften.

Wolf, Holger C. (2000), "Intranational Home Bias in Trade", Review of Economics and Statistics, Vol. 82, No. 4, pp. 555-563. 


\section{Appendix I}

Table 1: Total number of downsizing cases, by industry

\begin{tabular}{|c|c|c|c|}
\hline Industry & All firms & Domestic & Foreign \\
\hline M ining of coal and lignite & 4 & 1 & 3 \\
\hline M anufacture of food products & 12 & 5 & 7 \\
\hline Manufacture of beverages & 15 & 7 & 8 \\
\hline Manufacture of tobacco products & 8 & 0 & 8 \\
\hline M anufacture of wearing apparel & 9 & 5 & 4 \\
\hline M anufacture of paper and paper products & 3 & 1 & 2 \\
\hline Printing and reproduction of recorded media & 2 & 1 & 1 \\
\hline M anufacture of chemicals and chemical products & 20 & 15 & 5 \\
\hline Manufacture of basic pharmaceutical products and preparations & 27 & 17 & 10 \\
\hline Manufacture of other non-metallic mineral products & 10 & 6 & 4 \\
\hline M anufacture of basic metals & 6 & 4 & 2 \\
\hline M anufacture of computer, electronic and optical products & 80 & 38 & 42 \\
\hline Manufacture of electrical equipment & 31 & 22 & 9 \\
\hline Manufacture of machinery and equipment n.e.c. & 28 & 26 & 2 \\
\hline M anufacture of motor vehicles, trailers and semi-trailers & 41 & 30 & 11 \\
\hline Manufacture of other transp ort equipment & 17 & 9 & 8 \\
\hline Manufacture of furniture & 6 & 6 & 0 \\
\hline Other manufacturing & 12 & 10 & 2 \\
\hline Electricity, gas, steam and air conditioning supply & 10 & 9 & 1 \\
\hline Construction of buildings \& Civil engineering & 18 & 13 & 5 \\
\hline Wholesale and retail trade and repair of motor vehicles and motorcy cles & 3 & 1 & 2 \\
\hline Wholesale trade, except of motor vehicles and motorcy cles & 3 & 3 & 0 \\
\hline Retail trade, except of motor vehicles and motorcycles & 43 & 26 & 17 \\
\hline Land transport and transport via pip elines & 16 & 16 & 0 \\
\hline Water transport & 1 & 1 & 0 \\
\hline Air transport & 2 & 1 & 1 \\
\hline Publishing activities & 33 & 30 & 3 \\
\hline Motion picture, video and TV programme production, sound recording & 14 & 5 & 9 \\
\hline Programming and broadcasting activities & 3 & 3 & 0 \\
\hline Telecommunications & 28 & 11 & 17 \\
\hline Computer programming, consultancy and related activities & 3 & 1 & 2 \\
\hline Financial service activities, except insurance and pension funding & 42 & 38 & 4 \\
\hline Insurance, reinsurance \& pension funding, ex. compulsory social security & 24 & 16 & 8 \\
\hline Activities auxiliary to financial services and insurance activities & 1 & 1 & 0 \\
\hline Real estate activities & 5 & 3 & 2 \\
\hline Employment activities & 1 & 0 & 1 \\
\hline Information service activities & 39 & 34 & 5 \\
\hline Travel agency, tour op erator \& other reservation service/related activities & 4 & 3 & 1 \\
\hline Other services & 11 & 8 & 3 \\
\hline
\end{tabular}

One observation is one downsizing case. We use the two-digit classification of Destatis from 2008. Columns (1) to (3) summarize the total number of observations for each industry, by ownership. Note: Berlinwasser has unclear/shared control rights (see page 11 for more details). Thus, the company is neither classified as foreign nor as domestic firm. The company is the only firm in our sample that operates in the water supply industry, which is not reported in the table. 
Table 2: Classification of downsizing cases

\begin{tabular}{|c|c|c|c|}
\hline \multicolumn{4}{|c|}{ Panel A } \\
\hline & & \multicolumn{2}{|c|}{ Headquarters } \\
\hline & & Domestic & Foreign \\
\hline \multirow{7}{*}{$\begin{array}{l}\text { Sum of the shares of } 1-3 \\
\text { foreign blockholders }\end{array}$} & $100 \%$ & \multicolumn{2}{|c|}{168} \\
\hline & $75-99 \%$ & 14 & - \\
\hline & $51-74 \%$ & 21 & - \\
\hline & $50 \%$ & 3 & 1 \\
\hline & $45-49 \%$ & 2 & - \\
\hline & $26-44 \%$ & 0 & - \\
\hline & $0-25 \%$ & 426 & - \\
\hline
\end{tabular}

\section{Panel B}

\begin{tabular}{|l|c|c|}
\hline Changing ownership during downsizing & 8 & - \\
\hline Shared/unclear control rights & 2 & - \\
\hline Two headquarters & \multicolumn{2}{|c|}{6} \\
\hline
\end{tabular}


Table 3: Break-down of firms by size (Panel A) and downsizing cases by total number of jobs shed (Panel B), both by origin of ownership

Panel A: Firms by size

\begin{tabular}{lcccc|c}
\hline Ownership & $\leq 750$ & $751-2500$ & $2501-7500$ & $>7500$ & All \\
& & & & & \\
\hline & 102 & 116 & 106 & 100 & 424 \\
All firms & & & & & \\
& & & & & \\
\hline & & & & & \\
Domestic & $(62 \%)$ & $(58 \%)$ & $(54 \%)$ & $(74 \%)$ & $(62 \%)$ \\
& 39 & 49 & 49 & 26 & 163 \\
Foreign & $(38 \%)$ & $(42 \%)$ & $(46 \%)$ & $(26 \%)$ & $(38 \%)$ \\
& & & & \\
\hline \hline
\end{tabular}

Panel B: Total number of jobs shed per downsizing case

\begin{tabular}{lccc|c}
\hline Total number of job sheds & $\leq 150$ & $151-750$ & $>750$ & All \\
& 168 & 311 & 156 & 635 \\
\hline All cases & & & & \\
& 115 & 198 & 113 & 426 \\
Domestic & $(68 \%)$ & $(64 \%)$ & $(72 \%)$ & $(67 \%)$ \\
& 53 & 113 & 43 & 209 \\
Foreign & $(32 \%)$ & $(36 \%)$ & $(28 \%)$ & $(33 \%)$ \\
& & & & \\
\hline \hline
\end{tabular}

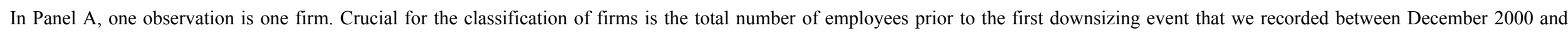
September 2008. Firms with changing ownership between different downsizing events are recorded under both categories. In Panel B, one observation is one downsizing case. 
Table 4: Coverage per job shed (Panel A), mean number of words in the entire articles and the downsizing parts of the articles (Panel B), by origin of ownership

\section{Panel A: Coverage per job shed}

Mean number of words per Mean number of articles

Ownership Observations job shed per 1,000 jobs shed

\begin{tabular}{llll}
\hline All cases & 635 & $2.38(3.58)$ & $18.10(22.23)$ \\
\hline Domestic & 426 & $1.71(2.19)$ & $15.43(18.11)$ \\
Foreign & 209 & $3.76(5.13)$ & $23.55(28.14)$ \\
\hline
\end{tabular}

Panel B: Coverage per article

Mean number of words in Mean number of words reporting on
Ownership Observations
the whole article
downsizing per article

\begin{tabular}{lccc} 
All firms & 5172 & $388.83(295.97)$ & $148.45(128.37)$ \\
\hline Domestic & 3288 & $388.96(287.87)$ & $137.75(114.48)$ \\
Foreign & 1884 & $388.61(309.67)$ & $167.12(147.75)$ \\
\hline
\end{tabular}

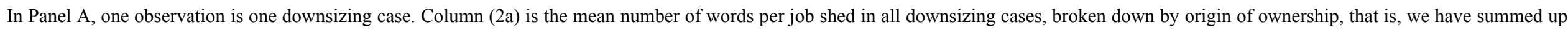

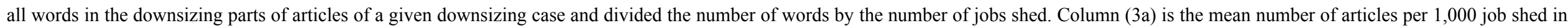

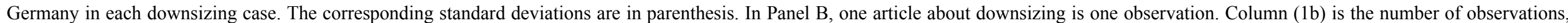

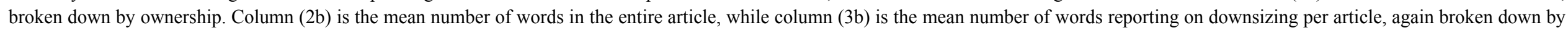
origin of ownership. The corresponding standard deviations are in parenthesis. 
Table 5: Downsizing reports, by newspaper section

\begin{tabular}{|c|c|c|c|c|c|}
\hline & \multicolumn{5}{|c|}{ Panel A: Frequency of articles } \\
\hline & Front-page & Political section & Business section & Finance section & other sections \\
\hline All firms $(n=5172)$ & $2.36 \%$ & $2.63 \%$ & $79.20 \%$ & $5.85 \%$ & $10.00 \%$ \\
\hline Domestic $(n=3288)$ & $2.31 \%$ & $2.65 \%$ & $76.86 \%$ & $8.15 \%$ & $10.10 \%$ \\
\hline Foreign $(n=1884)$ & $2.44 \%$ & $2.60 \%$ & $83.28 \%$ & $1.86 \%$ & $9.82 \%$ \\
\hline
\end{tabular}

Panel B: Mean number of words (in the entire articles)

\begin{tabular}{|c|c|c|c|c|c|}
\hline All firms & $186(106)$ & $691(413)$ & 372 (279) & 375 (217) & $500(368)$ \\
\hline Domestic & $194(106)$ & 709 (446) & $372(296)$ & $384(220)$ & $484(365)$ \\
\hline Foreign & $172(104)$ & $659(350)$ & $372(296)$ & 303 (179) & $527(373)$ \\
\hline
\end{tabular}

Panel C: Mean number of words (in the downsizing part of the articles)

\begin{tabular}{|c|c|c|c|c|c|}
\hline All firms & $117(77)$ & 179 (205) & $152(127)$ & $102(52)$ & $149(143)$ \\
\hline Domestic & $112(65)$ & $161(169)$ & 143 (119) & $100(51)$ & $132(105)$ \\
\hline Foreign & $123(93)$ & $210(255)$ & $167(140)$ & $119(54)$ & 180 (189) \\
\hline
\end{tabular}

Articles about downsizing in Die Welt appear mainly in 4 sections of the newspaper (front page, political section, business section, finance section). Articles in other sections of the newspaper are summed up in other sections. Panel A shows the distribution in which recorded articles appeared (in \%), by origin of ownership. Panel B shows the mean number of words in entire articles and Panel $\mathrm{C}$ the mean number of words in the downsizing part of the articles recorded, both by newspaper section. In Panel $\mathrm{B}$ and $\mathrm{C}$, the corresponding standard deviations are in parenthesis. 
Table 6: Articles and words by weekday

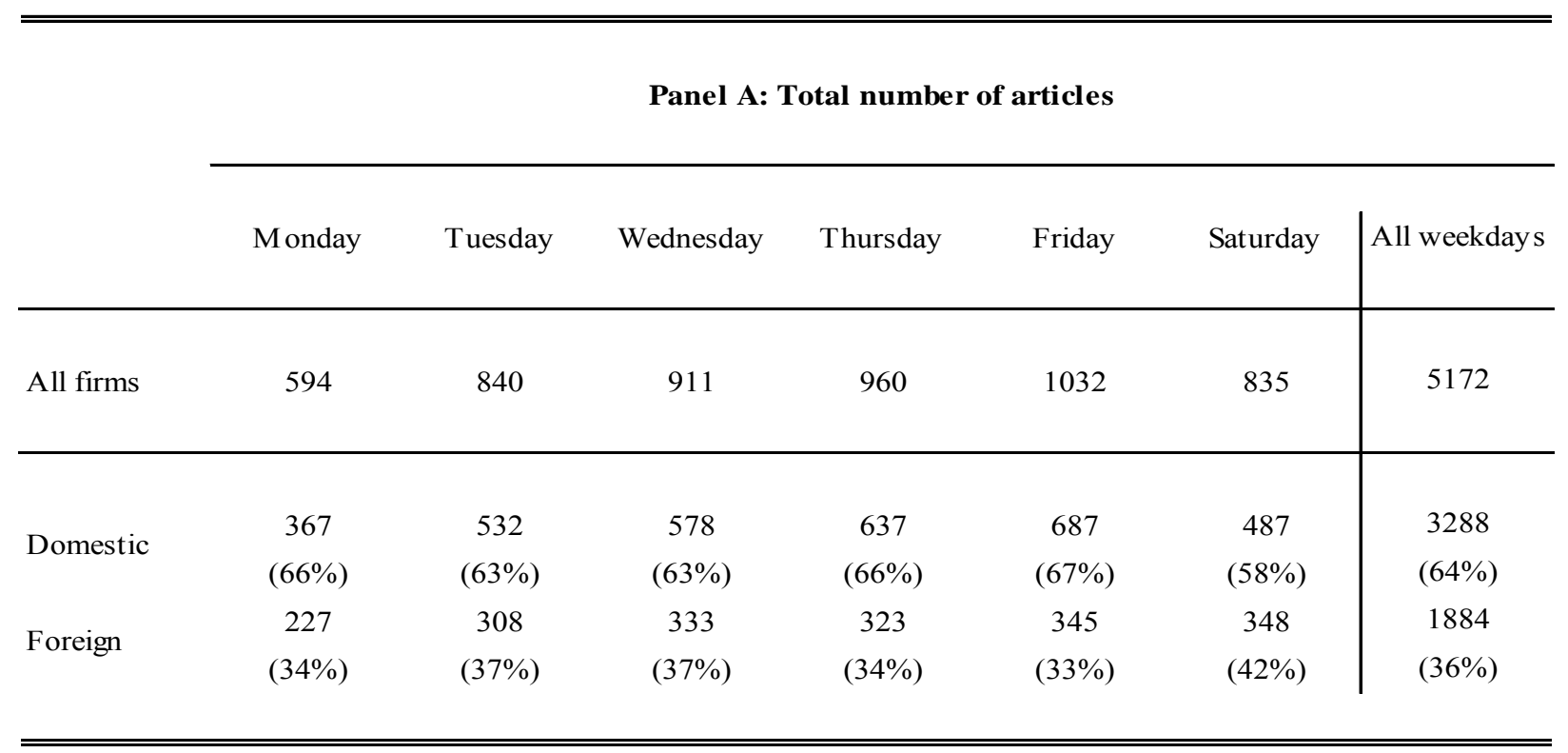

Panel B: Mean number of words in the downsizing part of the articles

\begin{tabular}{lllllll|l}
\hline All firms & $152(124)$ & $141(111)$ & $146(126)$ & $149(130)$ & $149(138)$ & $154(135)$ & $148(128)$ \\
\hline Domestic & $141(113)$ & $135(105)$ & $139(115)$ & $138(112)$ & $136(125)$ & $138(112)$ & $138(114)$ \\
Foreign & $169(139)$ & $152(121)$ & $157(142)$ & $172(156)$ & $176(158)$ & $177(160)$ & $167(147)$ \\
\hline \hline
\end{tabular}

Total number of articles on downsizing (Panel A) and words in the downsizing parts of the articles (Panel B), by origin and weekday. In Panel B, the corresponding standard deviations are in parenthesis. 
Table 7: Determinants of coverage per job shed, OLS

\begin{tabular}{|c|c|c|c|c|c|c|c|c|}
\hline \multirow[b]{2}{*}{ Specifications } & \multicolumn{4}{|c|}{ Panel A: Words per job shed } & \multicolumn{4}{|c|}{ Panel B: Articles per 1,000 jobs shed } \\
\hline & (1a) & $(2 a)$ & $(3 a)$ & $(4 a)$ & (1b) & $(2 b)$ & $(3 b)$ & $(4 b)$ \\
\hline Constant & $\begin{array}{c}1.708 * * * \\
(0.106)\end{array}$ & $\begin{array}{c}-2.176^{* *} \\
(0.990)\end{array}$ & $\begin{array}{c}-2.207 * * \\
(0.948)\end{array}$ & $\begin{array}{c}-2.161 * * \\
(0.992)\end{array}$ & $\begin{array}{c}15.431 * * * \\
(0.878)\end{array}$ & $\begin{array}{l}-3.506 \\
(6.061)\end{array}$ & $\begin{array}{l}-3.726 \\
(5.793)\end{array}$ & $\begin{array}{l}-3.352 \\
(6.114)\end{array}$ \\
\hline Foreign & $\begin{array}{c}2.050 * * * \\
(0.370)\end{array}$ & $\begin{array}{c}1.597 * * * \\
(0.417)\end{array}$ & $\begin{array}{c}1.484 * * * \\
(0.417)\end{array}$ & $\begin{array}{c}1.607 * * * \\
(0.406)\end{array}$ & $\begin{array}{c}8.116^{* * *} \\
(2.133)\end{array}$ & $\begin{array}{l}4.965 * * \\
(2.085)\end{array}$ & $\begin{array}{c}4.163 * * \\
(2.069)\end{array}$ & $\begin{array}{c}5.072 * * \\
(2.087)\end{array}$ \\
\hline Absolute magnitude & & & $\begin{array}{l}-0.001 \\
(0.000)\end{array}$ & & & & $\begin{array}{c}-0.002 * * \\
(0.000)\end{array}$ & \\
\hline Relative magnitude & & & & $\begin{array}{l}-0.338 \\
(0.719)\end{array}$ & & & & $\begin{array}{l}-3.443 \\
(3.852)\end{array}$ \\
\hline $\mathrm{R}^{2}$ & 0.073 & 0.466 & 0.480 & 0.466 & 0.030 & 0.437 & 0.456 & 0.438 \\
\hline Sample Size & 635 & 635 & 635 & 635 & 635 & 635 & 635 & 635 \\
\hline Industry (Dummy) & No & Yes & Yes & Yes & No & Yes & Yes & Yes \\
\hline Time (Dummy) & No & Yes & Yes & Yes & No & Yes & Yes & Yes \\
\hline
\end{tabular}

One observation is one downsizing case in both Panel A and B. Dependent variables are the number of words per job shed (Panel A) and number of articles per 1000 jobs shed (Panel B). Foreign is dummy variable which are set to 1 for foreign ownership. In specifications (2) - (4) we include a dummy variable time for each month after the point in time in which at least $75 \%$ of the articles/words about the downsizing event had appeared. We furthermore include a dummy variable industry that follows the two-digit classification from Destatis, 2008. Absolute magnitude indicates the total number of job shed in the firm in Germany, Relative magnitude the number of jobs shed divided by the total number of workers employed by the firm in Germany. ${ }^{*} \mathrm{p}<0.1,{ }^{* *} \mathrm{p}<0.05, * * * \mathrm{p}<0.01$; robust standard errors are in parenthesis. 
Table 8: Regression results for number of words per job lost and articles per 1000 jobs lost in logs, OLS

\begin{tabular}{|c|c|c|c|c|c|c|}
\hline \multirow[b]{2}{*}{ Specifications } & \multicolumn{3}{|c|}{ Panel A: Ln (words per job shed) } & \multicolumn{3}{|c|}{ Panel B: Ln (articles per 1,000 jobs shed) } \\
\hline & (1a) & $(2 a)$ & (3a) & (1b) & $(2 b)$ & $(3 b)$ \\
\hline Constant & $\begin{array}{c}-1.653 * * * \\
(0.629)\end{array}$ & $\begin{array}{l}0.960^{*} \\
(0.567)\end{array}$ & $\begin{array}{l}-0.415 \\
(0.675)\end{array}$ & $\begin{array}{l}1.296^{* *} \\
(0.526)\end{array}$ & $\begin{array}{c}4.333 * * * \\
(0.454)\end{array}$ & $\begin{array}{c}3.119^{* * *} \\
(0.564)\end{array}$ \\
\hline Foreign & $\begin{array}{c}0.519 * * * \\
(0.104)\end{array}$ & $\begin{array}{c}0.487 * * * \\
(0.092)\end{array}$ & $\begin{array}{c}0.444 * * * \\
(0.103)\end{array}$ & $\begin{array}{c}0.247 * * * \\
(0.090)\end{array}$ & $\begin{array}{c}0.211 * * * \\
(0.070)\end{array}$ & $\begin{array}{c}0.137 \\
(0.086)\end{array}$ \\
\hline Ln (magnitude) & & $\begin{array}{c}-0.508 * * * \\
(0.039)\end{array}$ & & & $\begin{array}{c}-0.590 * * * \\
(0.033)\end{array}$ & \\
\hline Ln (employment) & & & $\begin{array}{c}-0.115^{* * *} \\
(0.028)\end{array}$ & & & $\begin{array}{c}-0.170 * * * \\
(0.026)\end{array}$ \\
\hline $\begin{array}{l}\mathrm{R}^{2} \\
\text { Sample Size }\end{array}$ & $\begin{array}{c}0.435 \\
635\end{array}$ & $\begin{array}{c}0.575 \\
635\end{array}$ & $\begin{array}{c}0.456 \\
635\end{array}$ & $\begin{array}{c}0.421 \\
635\end{array}$ & $\begin{array}{c}0.657 \\
635\end{array}$ & $\begin{array}{c}0.465 \\
635\end{array}$ \\
\hline Industry (Dummy) & Yes & Yes & Yes & Yes & Yes & Yes \\
\hline Year (Dummy) & Yes & Yes & Yes & Yes & Yes & Yes \\
\hline
\end{tabular}

In column (2a) and (2b) we include total number of job sheds (in ln) and in column (3a) and (3b) total employment (in ln) by the downsizing firm in Germany as independent variables. ${ }^{*} \mathrm{p}<0.1, * * \mathrm{p}<0.05, * * * \mathrm{p}<0.01$; robust standard errors are in parenthesis.

Table 9: Mean number of articles per upsizing case, and coverage per job, by origin of ownership

\begin{tabular}{lccc}
\hline \hline & & $\begin{array}{c}\text { Mean number of words per } \\
\text { created new job }\end{array}$ & $\begin{array}{c}\text { Mean number of articles per } \\
1,000 \text { created new jobs }\end{array}$ \\
\hline All firms & 100 & $1.34(2.11)$ & $10.69(16.91)$ \\
\hline Domestic & 67 & $1.29(1.70)$ & $10.82(16.02)$ \\
Foreign & 33 & $1.49(2.77)$ & $10.43(18.85)$ \\
\hline \hline
\end{tabular}

We used the same algorithm as for the downsizing events to identify the coverage about upsizing. The only exception is that we did not conduct the corresponding experiments. The Table shows the number of observations, the mean number of words per created new job and the mean number of articles per 1,000 created new jobs, all by ownership. Standard deviations are in parenthesis. 
Table 10: Propensity score matching: Firm characteristics

\begin{tabular}{lcc}
\hline \hline & \multicolumn{3}{c}{ Panel A } \\
Specifications & $(1 \mathrm{a})$ & $(2 \mathrm{a})$ \\
\hline Average Treatment on the Treated & $\begin{array}{c}2.267^{* * *} \\
(0.481)\end{array}$ & $\begin{array}{c}2.057^{* * *} \\
(0.410)\end{array}$ \\
\hline Sample Size & 321 & 389 \\
\hline \hline & & Panel B \\
Specifications & $(1 \mathrm{~b})$ & $(2 \mathrm{~b})$ \\
\hline Average Treatment on the Treated & $2.305^{* * *}$ & $2.088^{* * *}$ \\
& $(0.417)$ & $(0.443)$ \\
\hline Sample Size & 308 & 365 \\
\hline \hline Industry (Dummy) & & \\
Number of employees & Yes & Yes \\
Region (Dummies) & Yes & \\
\hline \hline
\end{tabular}

Region is a dummy which is set to 1 for each German Bundesland where the company is headquartered. In Panel B we exclude all observations with a propensity score less than 0.1 or greater than 0.9 . Note that we cannot include Industry and Region dummies in one estimation as the balancing property is not satisfied. ${ }^{*} \mathrm{p}<0.1, * * \mathrm{p}<0.05, * * * \mathrm{p}<0.01$.

Table 11: Coverage per job shed, by quintiles of the mean unemployment rate

\begin{tabular}{|c|c|c|c|c|c|}
\hline \multirow{2}{*}{ Quintile } & \multirow{2}{*}{$\begin{array}{c}\text { Mean local } \\
\text { unemployment } \\
\text { rate }\end{array}$} & \multicolumn{2}{|c|}{ Observations } & \multicolumn{2}{|c|}{ Mean number of words per job shed } \\
\hline & & Domestic & Foreign & Domestic & Foreign \\
\hline 1 & $3.8-7.9 \%$ & 54 & 29 & $2.29(3.24)$ & $3.07(2.68)$ \\
\hline 2 & $7.94-10.1 \%$ & 51 & 32 & $2.08(2.71)$ & $3.31(2.44)$ \\
\hline 3 & $10.1-11.7 \%$ & 50 & 33 & $1.31(1.21)$ & $3.53(4.09)$ \\
\hline 4 & $11.7-14.21 \%$ & 46 & 37 & $1.34(1.08)$ & $4.22(5.80)$ \\
\hline 5 & $14.29-22 \%$ & 51 & 32 & $2.18(2.73)$ & $4.63(4.21)$ \\
\hline
\end{tabular}

The table shows the mean number of words per job shed by quintiles of the mean local unemployment rate. Mean local unemployment rate is the average quarterly unemployment rate in the cities or municipalities where the jobs are getting lost (according to Die Welt). Standard deviations are in parenthesis. Note that we lose some observations as we do not know the regions where the jobs are getting lost for all downsizing cases. As our sample includes 47 young high-tech firms that tend to locate in booming cities like Munich (which have low regional unemployment rates), we calculate the same descriptive statistics omitting all firms listed in NASDAQ and NEMAX/TecDAX. The main qualitative results are the same. 
Table 12: Regression results, controlling for type of ownership, OLS

\begin{tabular}{lc}
\hline \hline Constant & $-2.753^{* *}$ \\
& $(1.065)$ \\
Domestic, publicly listed & 0.519 \\
& $(0.400)$ \\
Domestic, privately owned & -0.536 \\
& $(0.584)$ \\
Domestic, multiple/other owners & 1.526 \\
& $(0.489)$ \\
Foreign, publicly listed & $1.658^{* * *}$ \\
& $(0.489)$ \\
Foreign, privately owned & $1.328^{*}$ \\
& $(0.773)$ \\
Foreign, private equity owned & $2.001^{* *}$ \\
& $(0.637)$ \\
Foreign, multiple/other owners & 6.679 \\
& $(4.207)$ \\
Domestic, state owned & Baseline \\
\hline R 2 & \\
Sample Size & 0.499 \\
\hline Tndustry (Dummy ) & 635 \\
\hline \hline
\end{tabular}

One observation is one downsizing case. We classified all firms into joint categories of type and origin of ownership and created a dummy for each of the following: Domestic, publicly listed; Domestic, privately owned; Domestic, state owned; Domestic, multiple/other owner; Foreign, publicly listed; Foreign, privately owned; Foreign, private equity owned and Foreign, multiple/other owners. Domestic, state owned is used as our baseline. Note that we have no domestic, private equity owned firms on our dataset. ${ }^{*} \mathrm{p}<0.1,{ }^{* *} \mathrm{p}<0.05$, $* * * \mathrm{p}<0.01$; robust standard errors are in parenthesis.
Table 13: Regression results, controlling for country of ownership, OLS

\begin{tabular}{lc}
\hline \hline Constant & $-2.053^{* *}$ \\
& $(0.890)$ \\
Continental Europe & $1.547^{* *}$ \\
$(n=92)$ & $(0.723)$ \\
U.K./Ireland & $2.319^{* * *}$ \\
$(n=40)$ & $(0.581)$ \\
North America & $1.395^{* * *}$ \\
$(n=78)$ & $(0.450)$ \\
Japan & 1.998 \\
$(n=9)$ & $(1.409)$ \\
Others & 0.092 \\
$(n=6)$ & $(0.757)$ \\
\hline $\mathrm{R}^{2}$ & 0.469 \\
Sample Size & 635 \\
\hline Industry (Dummy) & Yes \\
Time (Dummy) & Yes \\
\hline \hline
\end{tabular}

Continental Europe includes Austria, Belgium, Denmark, Finland, French, Italy, Luxemburg, Nederland, Norway, Spain, Sweden and Switzerland. North America includes the Bahamas Canada and the U.S.A. and. Others includes China, South Corea, Malaysia, Taiwan and Australia. Some firms are controlled by investors from two different countries; the dummy is set to one for both countries. * $\mathrm{p}<0.1, * * \mathrm{p}<0.05, * * * \mathrm{p}<0.01$; robust standard errors are in parenthesis. 
Table 14: Number of observations and mean number of words per job shed, by establishment closure

\begin{tabular}{l|c|c|c|c}
\hline \hline & \multicolumn{2}{|c|}{ Observations } & \multicolumn{2}{|c}{$\begin{array}{c}\text { Mean number of } \\
\text { words per job shed } \\
\text { Domestic }\end{array}$} \\
& Domestic & Foreign & Foreign \\
\hline Establishment closure & 143 & 83 & $1.69(2.24)$ & $3.30(4.29)$ \\
No establishment closure & 169 & 94 & $1.86(2.49)$ & $4.28(4.83)$
\end{tabular}

Row (1) includes only downsizing cases where the firm closes one or more establishments. Row (2) includes only cases where no establishment got closed. Note that we lose some observations as we do not have the information whether the firm closes an establishment or not for all downsizing cases. In Column (3) and (4) Standard deviations are in parenthesis.

Table 15: Regression results, controlling for establishment closure, OLS

\begin{tabular}{lcc}
\hline \hline Specifications & $(1)$ & $(2)$ \\
\hline Constant & 2.761 & 2.811 \\
& $(2.081)$ & $(2.650)$ \\
Foreign & $\begin{array}{c}1.222^{* *} \\
(0.557)\end{array}$ & $\begin{array}{c}1.498^{* * *} \\
(0.553)\end{array}$ \\
& & \\
\hline $\mathrm{R}^{2}$ & 0.757 & 0.716 \\
Sample Size & 226 & 263 \\
& & \\
\hline \multirow{2}{*}{ Industry (Dummy) } & Yes & Yes \\
Time (Dummy) & Yes & Yes \\
& & \\
\hline \hline
\end{tabular}

Column (1) includes only downsizing cases where an establishment is getting closed, column (2) cases where no establishment is getting closed. Note that we lose some observations as we do not have the information whether the firm closes an establishment or not for all downsizing cases. As we have "only" 226 (or 263) observations in those regressions, using 94 monthly time dummies could bias the results. Hence we run the same regressions using yearly time dummies. The main results (see Table $\mathrm{P}$ in the web appendix) are the same. ${ }^{*} \mathrm{p}<0.1, * * \mathrm{p}<0.05, * * *$ $\mathrm{p}<0.01$; robust standard errors are in parenthesis. 
Table 16: Propensity score matching: Characteristics of the downsizing event

\begin{tabular}{|c|c|c|c|}
\hline Specifications & (1a) & $\begin{array}{c}\text { Panel A } \\
(2 a)\end{array}$ & (3a) \\
\hline Average Treatment on the Treated & $\begin{array}{c}2.306 * * * \\
(0.655)\end{array}$ & $\begin{array}{c}1.889 * * \\
(0.726)\end{array}$ & $\begin{array}{c}2.293 * * * \\
(0.478)\end{array}$ \\
\hline \multirow[t]{2}{*}{ Sample Size } & 143 & 113 & 226 \\
\hline & (1b) & $\begin{array}{c}\text { Panel B } \\
(2 b)\end{array}$ & (3b) \\
\hline Average Treatment on the Treated & $\begin{array}{c}2.306 * * * \\
(0.653)\end{array}$ & $\begin{array}{l}1.902 * * \\
(0.740)\end{array}$ & $\begin{array}{c}2.683 * * * \\
(0.498)\end{array}$ \\
\hline Sample Size & 143 & 110 & 212 \\
\hline Absolut magnitude & Yes & Yes & Yes \\
\hline Downsizing speed & Yes & Yes & \\
\hline Establishment closure & Yes & Yes & Yes \\
\hline Mean local unemployment & Yes & Yes & Yes \\
\hline Industry (Dummy) & & Yes & \\
\hline Region (Dummies) & & & Yes \\
\hline
\end{tabular}

Downsizing speed is the speed of downsizing as reported in the newspaper. Establishment closure is a dummy set to one if the firm closes an establishment. The balancing property is satisfied in all regressions; we cannot include both regional and industry dummies as the balancing property is not satisfied. The same is true for Downsizing speed and Region. In Panel B and D we exclude all observations with a propensity score less than 0.1 or greater than 0.9 . ${ }^{*} \mathrm{p}<0.1,{ }^{* *} \mathrm{p}<0.05,{ }^{* * *} \mathrm{p}<0.01$. 
Table 17: Regression results when controlling for reasons of downsizing, OLS

\begin{tabular}{|c|c|c|}
\hline Specifications & (1) & (2) \\
\hline Constant & $\begin{array}{c}-2.696^{* *} \\
(1.204)\end{array}$ & $\begin{array}{c}-3.282 * * \\
(1.289)\end{array}$ \\
\hline Foreign & $\begin{array}{c}1.600 * * * \\
(0.434)\end{array}$ & $\begin{array}{l}1.490 * * \\
(0.465)\end{array}$ \\
\hline State intervention & $\begin{array}{l}2.511 * \\
(1.454)\end{array}$ & $\begin{array}{c}3.035 * * \\
(1.514)\end{array}$ \\
\hline Offshoring & $\begin{array}{c}0.143 \\
(0.720)\end{array}$ & $\begin{array}{c}0.607 \\
(0.809)\end{array}$ \\
\hline Insolvency & $\begin{array}{c}0.575 \\
(0.741)\end{array}$ & $\begin{array}{c}0.992 \\
(0.925)\end{array}$ \\
\hline Other reasons & $\begin{array}{c}0.565 \\
(0.682)\end{array}$ & $\begin{array}{c}1.001 \\
(0.776)\end{array}$ \\
\hline Multiple reasons & $\begin{array}{c}1.601 \\
(0.995)\end{array}$ & $\begin{array}{c}2.081 * * \\
(1.018)\end{array}$ \\
\hline $\mathrm{M} \& \mathrm{~A}$ & $\begin{array}{c}0.705 \\
(0.734)\end{array}$ & \\
\hline M\&A domestic & & $\begin{array}{c}0.759 \\
(0.867)\end{array}$ \\
\hline$M \& A$ foreign & & $\begin{array}{c}2.112 * * \\
(1.017)\end{array}$ \\
\hline No reason & Baseline & Baseline \\
\hline $\begin{array}{l}\mathrm{R}^{2} \\
\text { Sample Size }\end{array}$ & $\begin{array}{c}0.470 \\
635\end{array}$ & $\begin{array}{c}0.474 \\
635\end{array}$ \\
\hline $\begin{array}{l}\text { Industry (Dummy } \\
\text { Time (Dummy) }\end{array}$ & $\begin{array}{l}\text { Yes } \\
\text { Yes }\end{array}$ & $\begin{array}{l}\text { Yes } \\
\text { Yes }\end{array}$ \\
\hline
\end{tabular}

For each downsizing case, we identified the reason for downsizing, which is mentioned in the newspaper. The reasons given were classified in six categories with a dummy variable for each of the reasons: State intervention (firm destroys jobs as reaction to state intervention; the dummy is only set to 1 if the company (through a press communiqué) and the newspaper gives state intervention as the reason for downsizing); Offshoring, Insolvency $M \& A$ (jobs are shed because of the integration of the acquired/merged firm into the acquiring company after the merger), Other reasons, No reasons (no reasons are mentioned) and Multiple reasons (more than one reason is mentioned). We used No reasons as our baseline. Note that private equity investors restructuring a company after a takeover are categorized in other reasons and not in $M \& A$. In specifications (2) we split the $M \& A$ dummy in two variables. $M \& A$ domestic (acquiring firm is domestic owned) and $M \& A$ foreign (acquiring firm is foreign owned). $* \mathrm{p}<0.1, * * \mathrm{p}<0.05, * * *$ $\mathrm{p}<0.01$; robust standard errors are in parenthesis.
Table 18: Regression results, only including SMEs, OLS

\begin{tabular}{lc}
\hline \hline Constant & -2.679 \\
& $(3.401)$ \\
Foreign & $6.771 *$ \\
& $(3.645)$ \\
\hline $\mathrm{R}^{2}$ & 0.447 \\
Sample Size & 94 \\
& \\
\hline & \\
Industry (Dummy & Yes \\
Year (Dummy) & Yes \\
\hline \hline
\end{tabular}

Here we only including firms that employing 500 or less workers in Germany. Note that we use yearly time dummies as the number of observations is too small for using monthly time dummies. $* \mathrm{p}<0.1, * * \mathrm{p}<0.05$, *** $\mathrm{p}<0.01$; robust standard errors are in parenthesis.

\section{Table 19: Regression results, controlling for downsizing firms which advertise, OLS}

\begin{tabular}{lcc}
\hline \hline Specifications & $(1)$ & $(2)$ \\
\hline Constant & $-2.166^{* *}$ & $-2.149^{* *}$ \\
& $(1.00)$ & $(1.002)$ \\
Foreign & $1.586^{* * *}$ & $1.642^{* * *}$ \\
& $(0.416)$ & $(0.455)$ \\
Advertiser & -0.269 & \\
& $(0.261)$ & \\
Foreign_Advertiser & & -0.707 \\
& & $(0.568)$ \\
Domestic_Advertiser & & -0.235 \\
& & $(0.294)$ \\
\hline $\mathrm{R}^{2}$ & 0.466 & 0.467 \\
Sample Size & 635 & 635 \\
\hline Industry (Dummy) & Yes & Yes \\
Time (Dummy) & Yes & Yes \\
\hline \hline
\end{tabular}

Baseline regression, including a dummy which is set to 1 if the firms advertised in Die Welt in Nov. 2002, July 2005, Sept. 2006, May 2007 or May 2008. Column (2) includes an interaction terms of Advertiser and Foreign and Advertiser and Domestic. * $\mathrm{p}<0.1, * * \mathrm{p}<0.05$, *** $\mathrm{p}<0.01$; robust standard errors are in parenthesis. 
Table 20: Downsizing reports, by type of authorship

\begin{tabular}{|l|c|c|c|c|c|c|}
\hline \multirow{2}{*}{} & \multicolumn{3}{c|}{ All articles } & \multicolumn{3}{c|}{ Authors are known } \\
\cline { 2 - 8 } & $\begin{array}{l}\text { Number } \\
\text { of articles }\end{array}$ & $\begin{array}{l}\text { Mean number of } \\
\text { words, entire } \\
\text { article }\end{array}$ & $\begin{array}{l}\text { Mean number of } \\
\text { words about } \\
\text { downsizing }\end{array}$ & $\begin{array}{l}\text { Number of } \\
\text { articles }\end{array}$ & $\begin{array}{l}\text { Mean number of } \\
\text { words, entire } \\
\text { article }\end{array}$ & $\begin{array}{l}\text { Mean number of } \\
\text { words } \\
\text { downsizing }\end{array}$ \\
\hline All & 5,172 & $389(296)$ & $148(128)$ & 3,291 & $478(320)$ & $162(145)$ \\
\hline Domestic & 3,288 & $389(288)$ & $138(114)$ & 2,095 & $475(309)$ & $150(129)$ \\
\hline Foreign & 1,884 & $389(310)$ & $167(148)$ & 1,196 & $485(337)$ & $184(167)$ \\
\hline
\end{tabular}

\begin{tabular}{|l|c|c|c|c|c|c|}
\cline { 2 - 7 } & \multicolumn{4}{|c|}{ Authors are not known } & \multicolumn{2}{l}{$\begin{array}{l}\text { Authors are known, excluding articles from authors } \\
\text { with more than 50 articles in data set }\end{array}$} \\
\cline { 2 - 7 } & $\begin{array}{l}\text { Number } \\
\text { of articles }\end{array}$ & $\begin{array}{l}\text { Mean number of } \\
\text { words, entire } \\
\text { article }\end{array}$ & $\begin{array}{l}\text { Mean number of } \\
\text { words about } \\
\text { downsizing }\end{array}$ & $\begin{array}{l}\text { Number of } \\
\text { articles }\end{array}$ & $\begin{array}{l}\text { Mean number of } \\
\text { words, entire } \\
\text { article }\end{array}$ & $\begin{array}{l}\text { Mean number of } \\
\text { words } \\
\text { downsizing }\end{array}$ \\
\hline All & 1,881 & $232(154)$ & $125(87)$ & 1,983 & $473(308)$ & $169(145)$ \\
\hline Domestic & 1,193 & $239(158)$ & $117(80)$ & 1,286 & $473(305)$ & $159(135)$ \\
\hline Foreign & 688 & $221(145)$ & $138(98)$ & 697 & $472(314)$ & $187(161)$ \\
\hline
\end{tabular}

One article about downsizing is one observation. The table consists of four parts. Within each part, column (1) is the number of observations, column (2) is the mean number of words in the entire article and column (3) the mean number of words reporting on downsizing per article, all broken down by origin of ownership. The first part of the table reports the statistics for all articles, the second part for those articles where the authors are known and the third part for those where the authors are not known. Table 4 provides the same statistics only including those articles where the authors have written more than 50 articles of our dataset. Standard deviations are in parenthesis.

Table 21: Regression results, excluding downsizing cases in which authors with 50 or more articles are significantly involved, OLS

\begin{tabular}{lcc}
\hline \hline Specifications & $(1)$ & $(2)$ \\
\hline Constant & 2.760 & -1.157 \\
Foreign & $(1.838)$ & $(0.153)$ \\
& $\begin{array}{c}1.692^{* * *} \\
(0.539)\end{array}$ & $\begin{array}{c}2.000^{* * *} \\
(0.690)\end{array}$ \\
\hline $\mathrm{R}^{2}$ & 0.432 & 0.466 \\
Sample Size & 475 & 403 \\
\hline Industry (Dummy) & Yes & Yes \\
Year (Dummy) & Yes & Yes \\
\hline \hline
\end{tabular}

The table shows our baseline regression. In column (1) we exclude all downsizing cases from our dataset on which one or several of the journalists with 50 or more articles on downsizing wrote $50 \%$ or more of the articles on this downsizing case. In column (2) we set the threshold to $30 \%$. ${ }^{*} \mathrm{p}<0.1, * * \mathrm{p}<0.05, * * * \mathrm{p}<0.01$; robust standard errors are in parenthesis. 
Table 22: Downsizing reports in the seven leading national newspapers for five randomly selected months, by origin of owner

\begin{tabular}{|c|c|c|c|c|c|c|c|}
\hline & \multicolumn{7}{|c|}{ Panel A: Total number of articles about downsizing } \\
\hline & $\begin{array}{l}\text { Taz } \\
\text { (left) }\end{array}$ & $\begin{array}{c}\text { FR } \\
\text { (left-center) }\end{array}$ & $\begin{array}{c}\text { SZ } \\
\text { (left-center) }\end{array}$ & $\begin{array}{c}\text { FAZ } \\
\text { (right-center) }\end{array}$ & $\begin{array}{c}\text { Die Welt } \\
\text { (right-center) }\end{array}$ & $\begin{array}{c}\text { Handelsblatt } \\
\text { (business) }\end{array}$ & $\begin{array}{c}\text { FTD } \\
\text { (business) }\end{array}$ \\
\hline All firms & 86 & 129 & 143 & 150 & 351 & 192 & 209 \\
\hline Domestic & 63 & 84 & 100 & 112 & 246 & 128 & 138 \\
\hline Foreign & 23 & 45 & 43 & 38 & 105 & 64 & 71 \\
\hline
\end{tabular}

Panel B: Mean number of words in the downsizing part of the articles

\begin{tabular}{|c|c|c|c|c|c|c|c|}
\hline All firms & $\begin{array}{c}201.7 \\
(217.3)\end{array}$ & $\begin{array}{l}126.0 \\
(84.6)\end{array}$ & $\begin{array}{c}185.3 \\
(145.7)\end{array}$ & $\begin{array}{c}217.8 \\
(145.9)\end{array}$ & $\begin{array}{c}141.6 \\
(105.7)\end{array}$ & $\begin{array}{c}308.2 \\
(240.1)\end{array}$ & $\begin{array}{l}124.8 \\
(88.8)\end{array}$ \\
\hline Domestic & $\begin{array}{c}188.2 \\
(222.7)\end{array}$ & $\begin{array}{l}116.0 \\
(75.4)\end{array}$ & $\begin{array}{c}172.7 \\
(121.9)\end{array}$ & $\begin{array}{c}208.6 \\
(138.6)\end{array}$ & $\begin{array}{c}135.5 \\
(101.1)\end{array}$ & $\begin{array}{c}293.8 \\
(250.2)\end{array}$ & $\begin{array}{l}121.7 \\
(77.1)\end{array}$ \\
\hline Foreign & $\begin{array}{l}238.7 \\
(201.9)\end{array}$ & $\begin{array}{l}144.5 \\
(97.8)\end{array}$ & $\begin{array}{c}214.8 \\
(188.2)\end{array}$ & $\begin{array}{c}244.7 \\
(164.4)\end{array}$ & $\begin{array}{c}155.9 \\
(155.2)\end{array}$ & $\begin{array}{c}336.9 \\
(217.4)\end{array}$ & $\begin{array}{c}130.8 \\
(108.3)\end{array}$ \\
\hline
\end{tabular}

Panel A reports the total number of articles reporting about downsizing in November 2002, July 2005, September 2006, May 2007 and May 2008 for TAZ, SZ, FAZ, Die Welt, Handelsblatt and FTD, broken down by ownership. Panel B reports the mean number of words reporting on downsizing per articles for TAZ, SZ, FAZ, Die Welt, Handelsblatt and FTD. Standard deviations are in parenthesis. Panel A and B also report the same data for FR, but only for July 2005, September 2006, May 2007 and May 2008 as the data for November 2002 were not available in LexisNexis. 
Figure 1: Distribution of the articles about downsizing, by ownership and evaluation

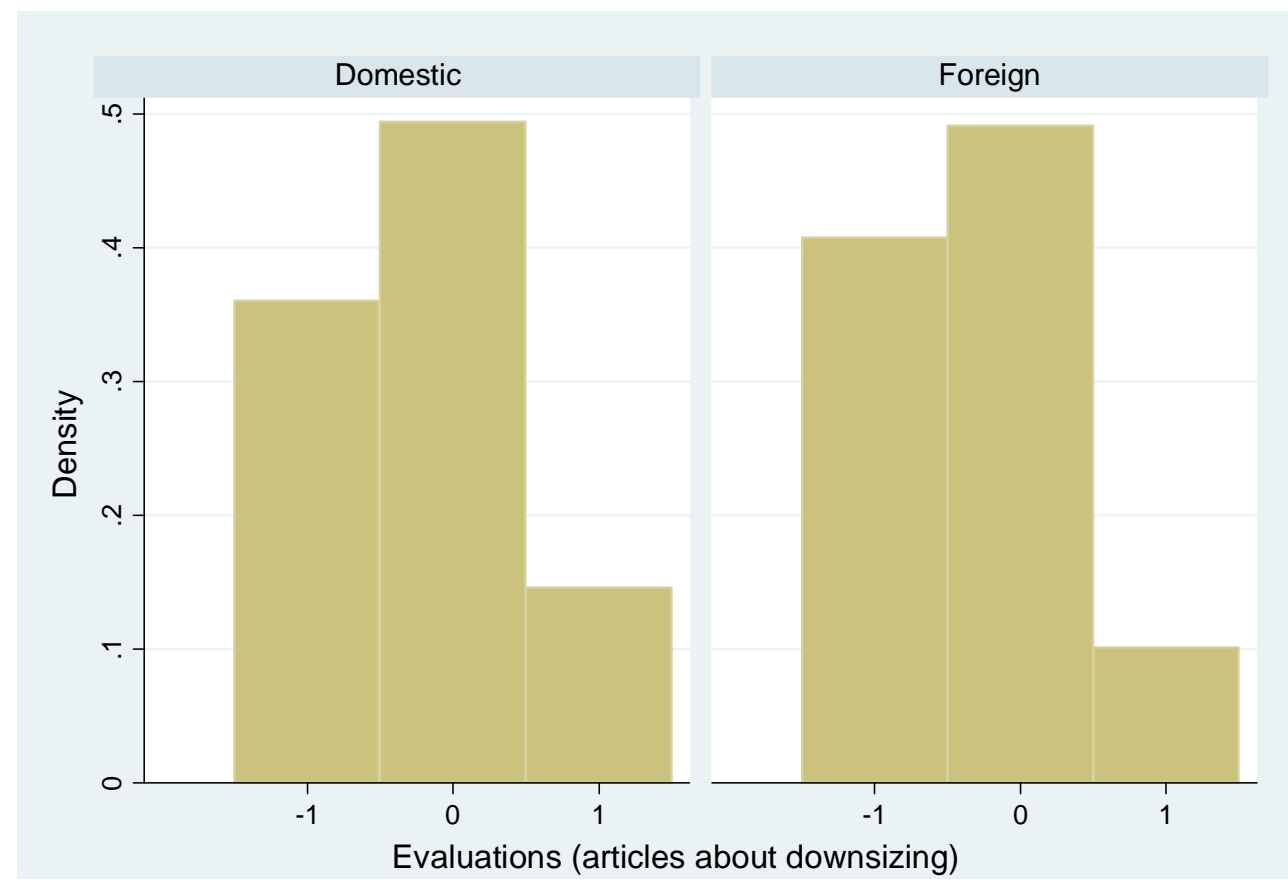

Figure 2: Distribution of the articles not related to downsizing, by ownership and evaluation

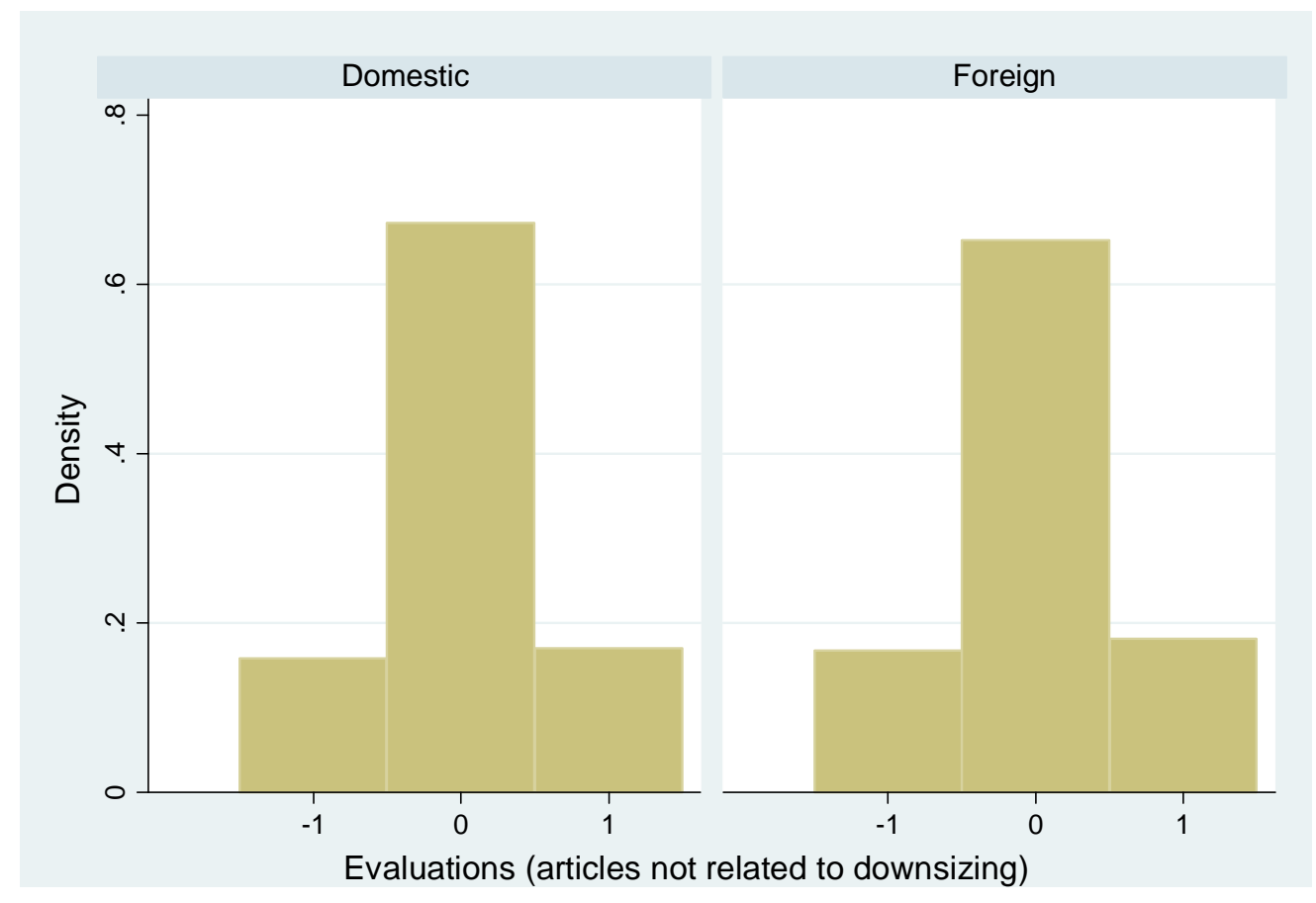


Figure 3: Mean number of words per job shed across unemployment rate quintiles, lowest (1) to highest (5), by ownership

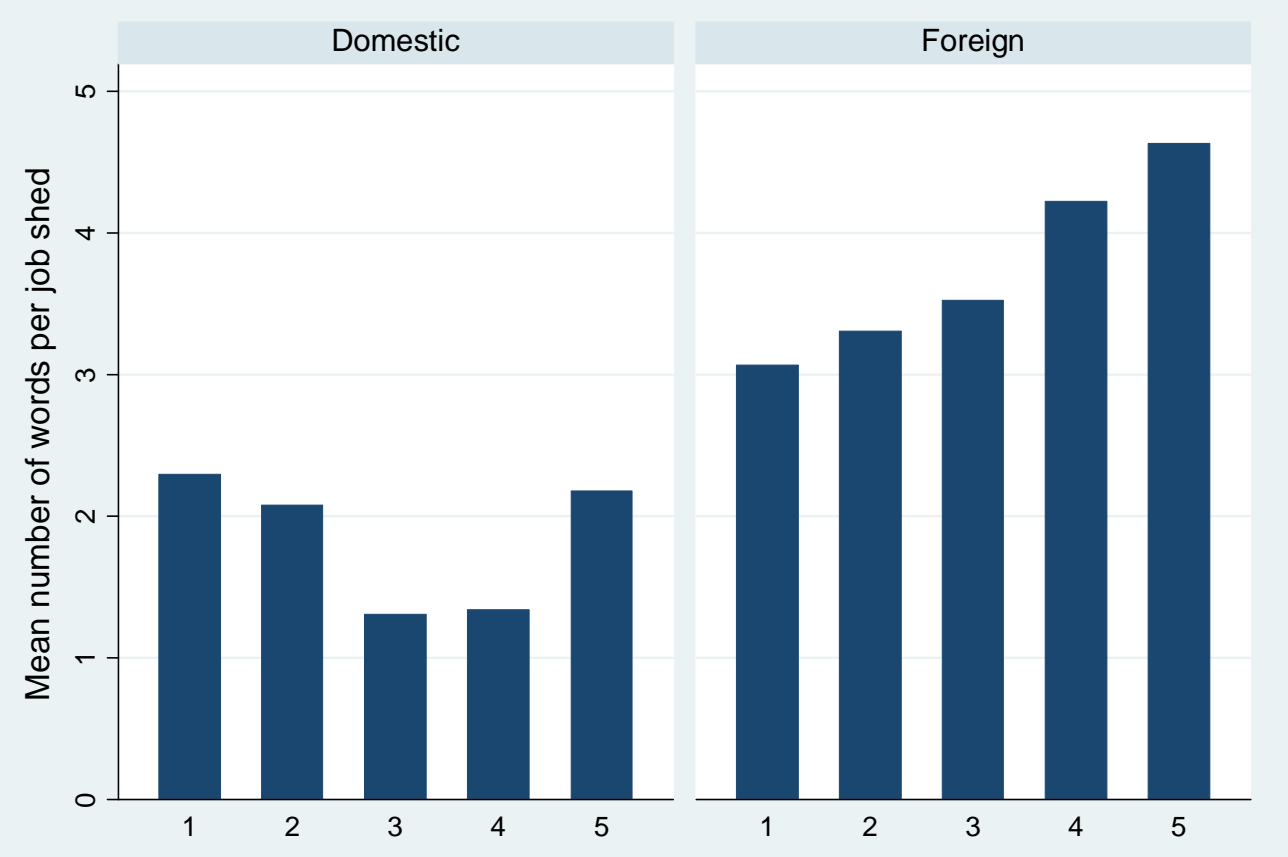




\section{Appendix II}

\section{Example for an article that qualified to be included in our data base:}

Arbeitsplatzabbau beginnt; Leifheit. Der Haushaltswaren-Anbieter Leifheit will im April mit dem Abbau von 400 Arbeitsplätzen beginnen. Vorstand Frank Gutzeit sagte, der Abbau solle bis Jahresende abgeschlossen sein: "Wir gehen davon aus, daß das eine einmalige Aktion ist." Leifheit verzeichnet seit einigen Jahren Rückgänge bei Umsatz und Ergebnis.

Job reduction begins; Leifheit. The white goods producer Leifheit will begin by April with a reduction of 400 jobs. Member of the board Frank Gutzeit said that this reduction will be finalized by the end of the year: "We expect that this is a one-shot action". Over the last few years, Leifheit's sales and profits have been decreasing.

\section{Example for an article that did not qualify:}

Metallindustrie streicht 35000 Stellen. Berlin - Der Stellenabbau in der Metall- und Elektroindustrie hat sich in den ersten sechs Monaten dieses Jahres spürbar beschleunigt. Nach den jüngsten Statistiken des Arbeitgeberverbandes Gesamtmetall, die der WELT vorliegen, sind seit Jahresbeginn rund 35000 Arbeitsplätze verloren gegangen. Damit hat sich die Zahl der abgebauten Arbeitsplätze gegenüber dem Vorjahr fast vervierfacht (9000 Stellen). "Das ist bedauerlich, weil es der Metall- und Elektroindustrie als einziger deutscher Branche gelungen ist, in den vergangenen zehn Jahren die Beschäftigung konstant zu halten", sagte Gesamtmetall-Hauptgeschäftsführerin Heike Maria Kunstmann. Der Verband erwartet weiterhin ein Wachstum von 3,0 Prozent für die Branche. "Welchen Kurs aber die Konjunktur im weiteren Verlauf des Jahres einschlagen wird, läßt sich noch nicht eindeutig voraussagen", sagte Gesamtmetall-Hauptgeschäftsführerin Heike Maria Kunstmann. Bei allen Prognosen sei große Vorsicht geboten. In den vergangenen vier Jahren sei der sicher geglaubte Aufschwung zweimal in sich zusammengefallen. Laut Statistik sind derzeit 532900 Menschen in der Metallindustrie arbeitslos - ein Plus von 6,7 Prozent gegenüber dem Vorjahr. Kunstmann: "Erfreulicherweise stiegen die bei den Arbeitsagenturen gemeldeten offenen gewerblichen Stellen um 6400 auf 50 800".

Metal industrie sheds 35000 jobs. Berlin - Job shedding in the metal and electric industry has increased during the last six months of this year. According to the newest statistics of the entrepreneurial association Gesamtmetall, which WELT has received, 35000 jobs have been lost since the beginning of the year. Thus the number of jobs that were shed has quadrupled compared to last year (9000 jobs). "We regret this, because during the last ten years the metal and electric industry has been the only one that succeeded to keep employment constant", said Gesamtmetall-Director Heike Maria Kunstmann. The association continues to expect a growth rate of 3\% in the industry. "We do not yet know which way the business cycle will go this year ", said Kunstmann. All predictions should be interpreted carefully. During the last few years the taken for granted boom has collapsed two times. According to statistics there are currently 532900 people unemployed in the industry, which represents a n increase of $6.7 \%$ compared to last year. Kunstmann: "Fortunatley, the labor agency has registered an increase by 6400 to 50800 vacancies compared to last year". 


\section{Synonyms for downsizing}

Panel A: German synonyms for the word downsizing

Abbau von Stellen

Anpassung der Mitarbeiterkapazitäten

Arbeitsplatzabbau

Arbeitsplatzverlust

Beschäftigungsabbau

Entlassung

Jobabbau

Jobs abbauen
Kündigung

Massenentlassung

Mitarbeiter entlassen

Personalabbau

Personalfreisetzung

Personalkürzung

Personalreduzierung

Schließung von Standorten
Schließung von Werken

Standort schließen

Stellen abbauen

Stellen streichen/gestrichen

Stellenabbau

Stellenstreichung

Werk schließen

Werkschließung

Panel B: German words that depending on the context indicate a downsizing event

\begin{tabular}{lll}
$\begin{array}{l}\text { Angestellte } \\
\text { Arbeitsplätze } \\
\text { Belegschaft }\end{array}$ & Beschäftigte & Personal \\
& Jobs & Stellen \\
Werke & \\
\hline Abfindungsprogramm & Ritarbeiter & Senkung der Verwaltungskosten \\
Einschnitte & Redionalisierung & Sozialplan \\
Einsparungen & Restrukturierung & Sparprogramm \\
Kapazitätsanpassung & Restrukturierungsprogramm & Sparprogramm \\
Kostenreduzierung & Sanierung & Umbau \\
Kostensenkung & Schieflage & Umstrukturierung \\
Kürzung & Schlankheitskur & \\
Neustrukturierung & Senkung der Personalkosten & \\
\hline \hline
\end{tabular}

\section{Synonyms for upsizing}

Panel A: German synonyms for the word upsizing
Arbeitsplätze schaffen
Neue Jobs
Stellen schaffen
Jobs schaffen
Neue Stellen
Neue Arbeitsplätze
Mitarbeiter einstellen

Panel B: German words that depending on the context indicate an upsizing event

\begin{tabular}{lll}
$\begin{array}{l}\text { Arbeitsplätze } \\
\text { Jobs }\end{array}$ & $\begin{array}{l}\text { Mitarbeiter } \\
\text { Personen }\end{array}$ & Stellen \\
\hline Anlage & Fabrik & Richtfest \\
Ansiedelung & Fertigung & Standort \\
Ausbau & Filialnetz & Werk \\
Einstellungen & Großinvestition & [NAME OF THE LOCATION] \\
Einweihung & Jobmaschine & \\
Eröffnung & Produktionsstätte & \\
\hline
\end{tabular}

